\title{
Automation of the evaluation of bonded and unbonded prestressed concrete beams, according to brazilian and french code specifications
}

\section{Automatização da verificação de vigas em concreto com protensão aderente e não aderente, segundo as normas brasileira e francesa}
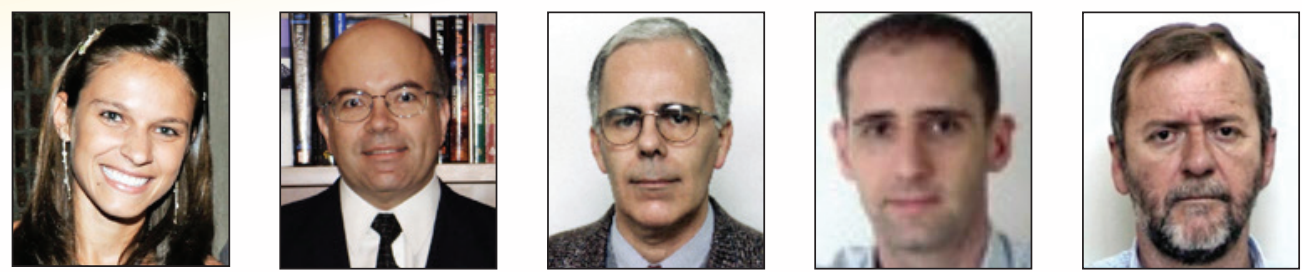

P. M. LAZZARI a

p.manica.lazzari@gmail.com

A. CAMPOS FILHO b americo@ufrgs.br

F. P. S. L. GASTAL

francisco.gastal@gmail.com

R. A. BARBIERI

r.barbieri@cte-sa.com

R. C. SCHWINGEL $e$

rubem@rs-engenharia.com

\begin{abstract}
This paper presents a suggestion for the automation of the design procedures of bonded and unbonded prestressed concrete flexural members, according to the Brazilian (NBR 6118:2007) and French (Règles BPEL 91) norm specifications. Prestressing of concrete structures has been increasingly used, mainly due to its building advantages, as well as allowing reducing crack incidence and element dimensions by the use of more resistant materials. Structure is analyzed by a numerical model that employs a hybrid type finite element for planar frames, considering geometric nonlinearity, cyclic loading and composite construction. The computational algorithm implemented considers full, partial and limited prestressing situations, evaluating in each case decompression limit state, limit state of cracking, ultimate limit state and final prestressing state. Finally, two examples comparing design situations according to the Brazilian and French norms are presented.
\end{abstract}

Keywords: prestressed concrete, structural design, hybrid type finite element.

\section{Resumo}

Este artigo apresenta uma proposta para a automatização dos procedimentos de projeto de peças fletidas de concreto com protensão aderente e não aderente, conforme recomendações das normas brasileira (NBR 6118:2007) e francesa (Règles BPEL 91). É crescente a utilização da protensão em estruturas de concreto, devido principalmente às suas vantagens construtivas, à redução na incidência de fissuras e à diminuição das dimensões das peças com o emprego mais eficiente dos materiais de maior resistência. A análise estrutural é feita através de um modelo numérico que utiliza elementos finitos do tipo híbrido para pórticos planos, considerando a não-linearidade geométrica, carregamentos cíclicos e construção composta. Nas rotinas computacionais implementadas são consideradas as situações de protensão completa, limitada e parcial e verificados conforme cada caso, os estados limites de descompressão, de formação e de abertura das fissuras, além dos estados limites últimos finais e no ato da protensão. Por fim, são apresentados dois exemplos que comparam situações de projeto, segundo as normas brasileira e francesa.

Palavras-chave: concreto protendido, projeto estrutural, elemento finito tipo híbrido.

Graduate Program in Civil Engineering, Federal University of Rio Grande do Sul, p.manica.lazzari@gmail.com, Av. Osvaldo Aranha - 99, $3^{\circ}$ andar, 90035-190, Porto Alegre, Rio Grande do Sul, Brasil;

b Graduate Program in Civil Engineering, Federal University of Rio Grande do Sul, americo@ufrgs.br, Av. Osvaldo Aranha - 99, 3andar, 90035-190, Porto Alegre, Rio Grande do Sul, Brasil;

Graduate Program in Civil Engineering, Federal University of Rio Grande do Sul, francisco.gastal@gmail.com, Av. Osvaldo Aranha - 99, $3^{\circ}$ andar, 90035-190, Porto Alegre, Rio Grande do Sul, Brasil;

d Structural designer, CPA Engenharia Ltda, r.barbieri@cte-sa.com, Av. Carlos Gomes, 1998 - conjunto 704/705, 90480-002, Porto Alegre, Rio Grande do Sul, Brasil;

- Graduate Program in Civil Engineering, Federal University of Rio Grande do Sul, rubem@rs-engenharia.com, Av. Osvaldo Aranha - 99, $3^{\circ}$ andar, 90035-190, Porto Alegre, Rio Grande do Sul, Brasil. 


\section{Introduction}

Prestressed concrete started to be scientifically developed in the beginning of the 20th century, and its use was consolidated in the 1940s. According to Rudloff [1], the prestressing of concrete structures is an intelligent, efficient, and enduring technology. It is intelligent because it profits from the mechanical strength both of iron and concrete, its main materials. It is efficient because it is technically better than conventional solutions, producing safer and more comfortable structures. And it is enduring because it promotes a long service life of its elements, and therefore the structures may need low or no maintenance.

Characteristics, such as covering long spans, better control and reduction of deflections and cracking, application in pre-cast elements, structural recovery and reinforcement, and the use of prestressing in slender elements, including beamless flat slabs, are some of the advantages of the widespread application of this technology both in conventional and bold architectural design, as well as in small, medium, and large works. The main economic advantages are reducing the amount of concrete and steel due to the efficient utilization of more resistant material, and the possibility of covering longer spans than conventional reinforced concrete by using slender elements.

This article presents the calculation routines implemented to automate the evaluation of the compliance of bonded and unbonded prestressed concrete flexural members to Brazilian (NBR 6118:2007) and French (Règles BPEL 91) specifications.

The program takes into consideration complete, limited and partial prestressing, and evaluates, in each case, decompression, cracking formation and width limit states, as well as final prestressing and ultimate limit states.

The structural analysis is made by employing the hybrid finite element for planar frames proposed by Barbieri [2], which allows using single finite long elements in the span of a beam or column. The implemented numerical model assumes a non-linear material behavior and concrete cracking, geometric nonlinearity, cyclic loading, and composite construction.

In this article, only some of the evaluation procedures recommended by the Brazilian and the French norms will be discussed. The complete text on these criteria was published by Lazzari [3]. In this article, two design situations, using bonded or unbonded partial prestressing and considering the use of bonded straight tendons or unbonded curved tendons, are analyzed. Crack width service limit state and ultimate limit state results are analyzed according to both norms.

\section{Numerical model}

The numerical model based on hybrid finite element formulation, proposed by Barbieri et al. [4], was used for the analysis of prestressed planar frames. Considering that the interpolation functions of this element are the equations describing force variation along a tendon, and that forces are interpolation variables, it is possible to use long elements and a single finite element to describe a member. This considerably reduces computational efforts. According to Barbieri [2], the theoretical exact character of the formulation, that is, the use of the equilibrium condition, independently from arbitrary hypothesis in the interpolation function, con- tributes for adequate modeling of unbonded tendons as the strain on these structures depends on the curvature of all sections of the prestressed element.

The adopted numerical model allows considering geometric nonlinearity, cyclic loading, and composite construction, which takes into account concrete placement in stages. With regards to the materials, nonlinear constitutive models for concrete, passive-reinforcement steel, and prestressing steel were employed, according to the literature. A five-element Maxwell chain was used to represent concrete and prestressing steel rheological behavior, taking into account the characteristics of each material.

\subsection{Structure discretization}

In the adopted numerical model, each tendon of the planar frame is represented by its reference longitudinal axis, which matches the finite element axis. Each finite element consists of two nodes: an initial and a final node. One or more finite elements presenting three degrees of freedom per node can be used to model each frame tendon.

An uneven discrete number of cross sections is defined for each finite element. The cross sections are used as integration points inside the element and define the properties along a tendon. When cross sections are evenly distributed in the element, the integration techniques of Simpson or Gauss-Lobatto can be used. Otherwise, that is, when cross section distribution is uneven, only the integration technique of Gauss-Lobatto can be applied. The results of this technique are more accurate compared with those obtained using Simpson's integration technique. Finite element stiffness and loading matrices are assembled by integrating cross sectional properties along its axis. Responses along the element, such as forces, strains, and displacements are obtained at those cross sections.

Integration modules along the element are subintervals with constant properties that, together, determine total integration interval, which corresponds to the element's length. These modules are used to confer numerical accuracy to the integration of discontinuous functions, such as long elements with geometrical, material or loading discontinuities along the axis. These discontinuities may be geometrical, when sections with different shapes are used, or material, when different materials are used in the same element, such as two concrete types. Passive or prestressing reinforcements and loadings are often discontinuous, such as in segmental prestressing or concentrated loadings, respectively.

An uneven number of thin horizontal planes of any width is distributed along the cross-sectional symmetry vertical axis. These horizontal planes represent integration points along the section height. Regarding the longitudinal axis, each cross section can be intercepted at any arbitrary point along the vertical axis, and not necessarily at the section's barycenter.

In addition to element integration models, there are also sectional integration models that are used as subintervals bearing homogenous properties in order to represent the discontinuities along the integration axis. Sudden changes in horizontal plane width, as in the case of sections I or T or in parts of the section containing different concrete types, which are common in beams and slabs, are some examples of possible discontinuities along section vertical axis.

Bonded or unbonded passive or active reinforcements are mod- 
eled as additional horizontal planes added to the section. Bonded reinforcement properties contribute to the element's stiffness matrix because they are added to section stiffness. On the other hand, unbonded reinforcements are considered as separate components acting on the structure. Reinforcement stresses and strains, including those of unbonded prestressed reinforcements, are determined at the element's integration points.

Relative to composite construction, new integration modules can be added to sections during analysis, as in the case of slabs cast on precast beams. In addition, other finite elements can be added to the structure at any time, simulating the subsequent continuity of precast members. The parameter time is used to control the evolution of the building and loading stages, even when the rheological behavior of materials is not considered in the analysis. An inclusion date is associated with every structural component, including section module, finite element, rebar, and prestressing tendons. Initial and final application dates are also defined for loading cases. Therefore, at each new loading, the numerical model compares the initial date of the loading case with the installation of each structural component, determining which components should be considered. In the case of self weight, only the section parts which inclusion date is the same as the initial loading date are considered. Also, only the tendons which installation dates are the same as the initial prestressing step date are elongated (Barbieri et al, [4]).

\subsection{Hybrid finite element formulation}

When formulating a hybrid finite element, it is possible to deduce the stiffness matrix, equivalent nodal load vector, and the element equation by considering the force interpolation function. During the analysis, an equation system, consisting of the stiffness matrix and of the load vector, is assembled and solved, using nodal displacements as unknown factors. These displacements are obtained by tendon force equilibrium equations. After nodal displacements are determined, structural node forces are calculated. Responses inside the finite element, including stresses, strains, and displacements, are determined by the interpolation of nodal forces (Voelcker, [5]).

Hybrid finite element formulation provides a distribution of curvatures inside the element bearing a theoretically exact character, based on the theoretically exact distribution of moments. Therefore, highly accurate curvature distributions allow the utilization of long finite elements. In addition, in the case of unbonded prestressed structural elements, the adequate evaluation of curvature distribution contributes to the correct estimation of prestressed reinforcement strains (Barbieri, [2]).

\subsection{Material constitutive models}

When analyzing the behavior of a structure, the knowledge on the constitutive equations representing material behavior is essential. These equations are compatible with the design of the structure; they model material behavior under predicted loading conditions, and involve a reduced number of variables in order not to reduce computational efficiency.

Two different models were used to describe the behavior of concrete. Saenz's equation (Kabaila et al., [6]) was adopted for prestressed concrete. This equation is used for concrete submitted to compressive loads in monotonic loadings, from no strain to strength peak, as shown in the equation (1) below.

$$
\sigma_{c}=\frac{E_{c} \varepsilon_{m}}{1+\left(\frac{E_{c} \varepsilon_{c 0}}{f_{c}}-2\right)\left(\frac{\varepsilon_{m}}{\varepsilon_{c 0}}\right)+\left(\frac{\varepsilon_{m}}{\varepsilon_{c 0}}\right)^{2}}
$$

where:

$\sigma_{c}:$ concrete stress;

$E_{c}:$ modulus of elasticity of concrete;

$\varepsilon_{m}:$ mechanical strain;

$f_{c}$ : compressive strength or peak strength;

$\varepsilon_{c o}$ : strain relative to peak strength.

The softening behavior of concrete after peak strength $\left(f_{c}\right)$ is modeled by a stress-linear strain ratio, as shown in equations (2) and (3), respectively, for concrete stress and tangent modulus of elasticity. The behavior of concrete submitted to compression is shown on Figure 1.

$$
\sigma_{c}=E_{c}^{t}\left(\varepsilon_{m}-\varepsilon_{c 0}\right)+f_{c}
$$

$$
E_{c}^{t}=\frac{f_{c f}-f_{c}}{\varepsilon_{c f}-\varepsilon_{c 0}}
$$

In concrete submitted to tensile stress in monotonic loadings, the response is considered linear up to cracking, and the modulus of elasticity is equal to the initial tangent modulus $\left(E_{c}\right)$. When tensile strength is reached in a section, it is considered that the section is cracked and that only the reinforcements contribute to tensile strength forces. However, when there are bonded reinforcements, concrete also contributes to tensile strength forces, thereby increasing element stiffness in the cracked zone. This behavior is called

Figure 1 - Concrete compression behavior

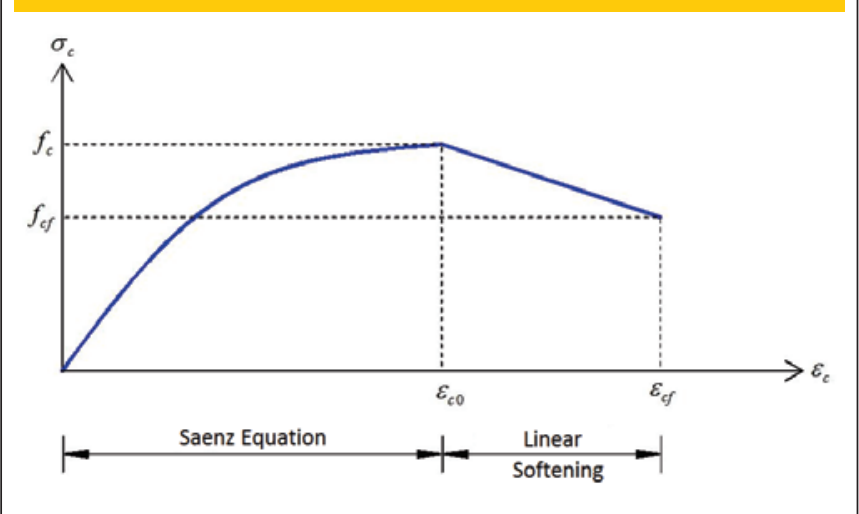


Figure 2 - Concrete tensile behavior

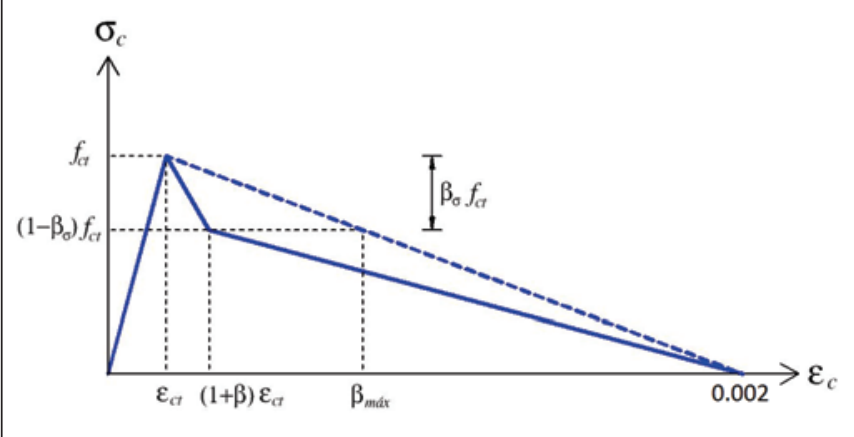

tension stiffening, and it is simulated by a slight reduction of concrete tension stress after stress $f_{c t}$ is exceeded. If this effect is not considered, displacements are usually overestimated (Ghali \& Favre, [7]). The tension stiffening effect occurs in two intervals: the first presents higher stress reduction $\left(\beta_{\sigma} f_{c t}\right)$ than the second. After an initial drop in strength, concrete stress gradually decreases at a constant rate until null value at $0.2 \%$ strain is reached. After $0.2 \%$ strain, stress and modulus of elasticity remain null. The above intervals are determined by parameters $\beta$ and $\beta_{\sigma}$ as shown in Figure 2 (Owen \& Figueiras, [8]). A bi-linear stress-strain curve was used for steel in passive reinforcements, where steel bars are represented as an elasto-plastic material, presenting the same tension and compression behavior. The curve of Devalapura \& Trados [9], shown in Figure 3, was used for prestressing steel, presenting continuous behavior along the entire strain interval and no defined yield point. Constants $A, B$, and $C$ were obtained from equations (5), (7), and (8), respectively. Constant $\mathrm{D}$ was determined by an iteractive process, solving equation (4) for yield stress $\left(\sigma_{p}=f_{p y}\right)$ and strain equal to $\left(\varepsilon_{p}=0.01\right)$.

$$
\sigma_{p}=\varepsilon_{p}\left\{A+\frac{B}{\left[1+\left(C \varepsilon_{p}\right)^{D}\right]^{\frac{1}{D}}}\right\}
$$

where:

$\varepsilon_{p}:$ strain in the prestressing reinforcement; $\sigma_{p}$ : stress in the prestressing reinforcement;

$A, B, C$ and $D$ : constants.

$$
A=E_{p s} \frac{f_{p u}-f_{s 0}}{\varepsilon_{p u} E_{p s}-f_{s 0}}
$$

$$
f_{s 0}=1.04 f_{p y}
$$

$$
B=E_{p s}-A
$$

$$
C=\frac{E_{p s}}{f_{s 0}}
$$

where:

$f_{p y}$ : conventional yield stress of the prestressing reinforcement relative to 0.01 strain;

$f_{s 0}$ : intersection of the tangents of the two linear segments of the curve.

\section{Design criteria}

\subsection{Brazilian norms}

Consistent with the global trend, the Brazilian norm NBR 6118 [10] gathered in a single text the general criteria for the design of structures made of simple concrete, reinforced concrete, and prestressed concrete. Depending on the prestressing degree (complete, limited, or partial), service limit states of decompression (SLS-D), crack formation (SLS-F), or crack width (SLS-W) are evaluated, as well as excessive strain service limit state (SLS-DEF), and final and prestressing ultimate limit states. Table 1 shows a summary of the required SLS evaluations for members submitted to the three prestressing levels, where EEC corresponds to the environmental exposure class.

Partial prestressing is characterized by a combination of active and passive reinforcements. In this type of prestressing, tensile stresses on concrete are allowed to reach higher values, resulting in crack widths lower than the limit value recommended by the norm $\left(w_{k \text {,limite }}=0.2 \mathrm{~mm}\right)$. Table 2 shows the concrete stresses allowed for each prestressing level. The allowable compressive

Figure 3 - Devalapura \& Trados (9) stressstrain relationship, for prestressing steel

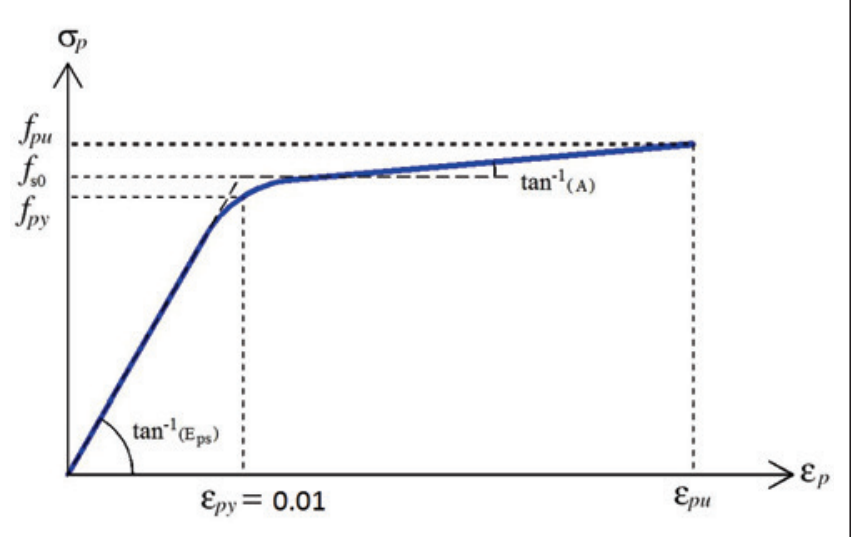




\section{Table 1 - Verification of Serviceability Limit State - Brazilian Code Specification (10)}

\begin{tabular}{|c|c|c|c|}
\hline & Prestressing Type/EEC & Load Combination & $\begin{array}{c}\text { Serviceability Limit State } \\
\text { (SLS) }\end{array}$ \\
\hline $\begin{array}{l}\text { Partial } \\
\text { Prestressing }\end{array}$ & $\begin{array}{l}\text { Pre-tension with EEC I or } \\
\text { Post-tension with EEC I and II }\end{array}$ & $\begin{array}{l}\text { Frequent load } \\
\text { combination }\end{array}$ & SLS-W $\left(w_{k} \leq 0.2 \mathrm{~mm}\right)$ \\
\hline $\begin{array}{l}\text { Limited } \\
\text { Prestressing }\end{array}$ & $\begin{array}{l}\text { Pre-tension with EEC II or } \\
\text { Post-tension with EEC III and IV }\end{array}$ & $\begin{array}{c}\text { Frequent load } \\
\text { combination } \\
\text { Quasi-permanent load } \\
\text { combination }\end{array}$ & $\begin{array}{l}\text { SLS-F } \\
\text { SLS-D }\end{array}$ \\
\hline $\begin{array}{c}\text { Full } \\
\text { Prestressing }\end{array}$ & Pre-tension with EEC III and IV & $\begin{array}{c}\text { Rare load combination } \\
\text { Frequent load } \\
\text { combination }\end{array}$ & $\begin{array}{l}\text { SLS-F } \\
\text { SLS-D }\end{array}$ \\
\hline
\end{tabular}

stress value of $0.5 f_{c k}$ was adopted because the validity of the formulation to consider strains caused by concrete yield is limited. The Brazilian norm recommends the use of the lower concrete tensile strength value, $f_{c t k i n f}$, as concrete tensile strength value, $f_{c t}$, shown in equation (9). Because the $f_{c t, \text { inf }}$ value corresponds to $70 \%$ of the $f_{c t m}$ value, and it needs to be multiplied by a factor equal to 1.5 in rectangular sections, resulting in $1.05 f_{c t m}$, the average tension strength $f_{c t m}$ was adopted, thereby favoring safety in $5 \%$. It must be mentioned that this tension limit is calculated when concrete is at State I, that is, it is not cracked and its materials present linear elastic behavior.

$f_{c t}=f_{c t m}=0.3 f_{c k}^{2 / 3}$

where:

$f_{c t m}$ : concrete average tensile strength (MPa);

$f_{c k}$ : concrete characteristic compressive strength (MPa).

In order to evaluate the service limit state of crack width, a subroutine that checks members with partial prestressing under frequent combination was implemented, considering item 17.3.3 of NBR 6118 [10]. The criteria presented in the norm are acceptable evaluations of the element's general behavior, as crack width is influenced by restrictions on structural volumetric variations and by execution conditions.

According to NBR 6118 [10], for each element or group of elements of the bonded active and passive reinforcement that control structural element cracking, except for unbonded tendons, a $A_{c r}$ area of the surrounding concrete, determined by a rectangle which sides are closer than $7.5 \mathrm{fi}$ of the reinforcement tendon axis, is considered. Figure 4 shows the surrounding concrete area described.

Figure 5 illustrates the automatic procedure used for the calculation of the $A_{c r}$ area. In each module of the cross section with stressed reinforcements, a grid with small rectangular elements is generated. This grid allows an approximate identification of the region of the $A_{c r}$ area in each tendon. Then, all the reinforcement tendons are checked to verify which are stressed, and the rectangles that are in their surrounding area are marked; overlapping areas are not taken into consideration. At the end of the process, the sum of the areas with marked rectangles corresponds to the $A_{c r}$ area.

According to item 17.3.3.2 of the Brazilian norm, characteristic crack width values, $w_{k 1}$ and $w_{k 2}$ (equations 12 and 13) are calculated, and the lowest value is used for comparison. Reinforcement rate and reinforcement stress at the center of gravity of the lay-

Table 2 - Concrete allowable stresses - Serviceability Limit State - Brazilian Code Specification (10)

\begin{tabular}{|c|c|c|c|c|}
\hline & & $\begin{array}{c}\text { Partial } \\
\text { Prestressing }\end{array}$ & $\begin{array}{l}\text { Limited } \\
\text { Prestressing }\end{array}$ & $\begin{array}{c}\text { Full } \\
\text { Prestressing }\end{array}$ \\
\hline \multirow{3}{*}{ Compression } & Quasi-permanent load combination & & \multirow{3}{*}{$0.5 \mathrm{f}_{\mathrm{ck}}$} & \\
\hline & Frequent load combination & & & \\
\hline & Rare load combination & & & \\
\hline \multirow{3}{*}{ Tension } & Quasi-permanent load combination & - & 0 & - \\
\hline & Frequent load combination & - & $f_{c t}$ & 0 \\
\hline & Rare load combination & - & - & $f_{c t}$ \\
\hline
\end{tabular}




\section{Figure 4 - Effective tension area of concrete around each steel bar}

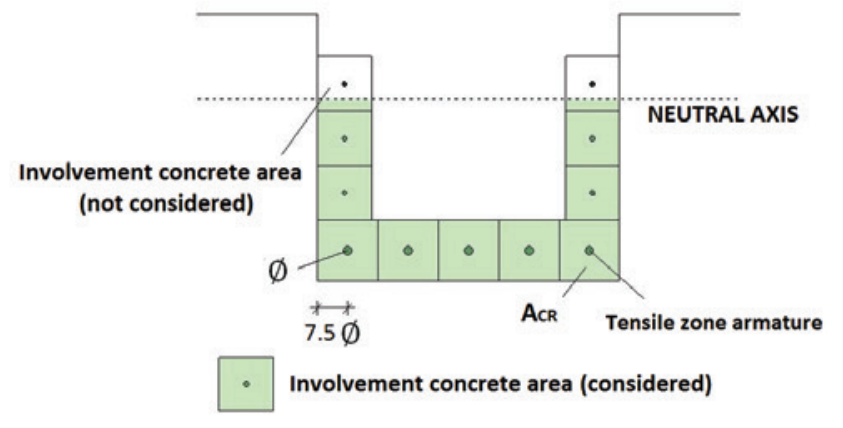

Figure 5 - Evaluation of the effective tension area

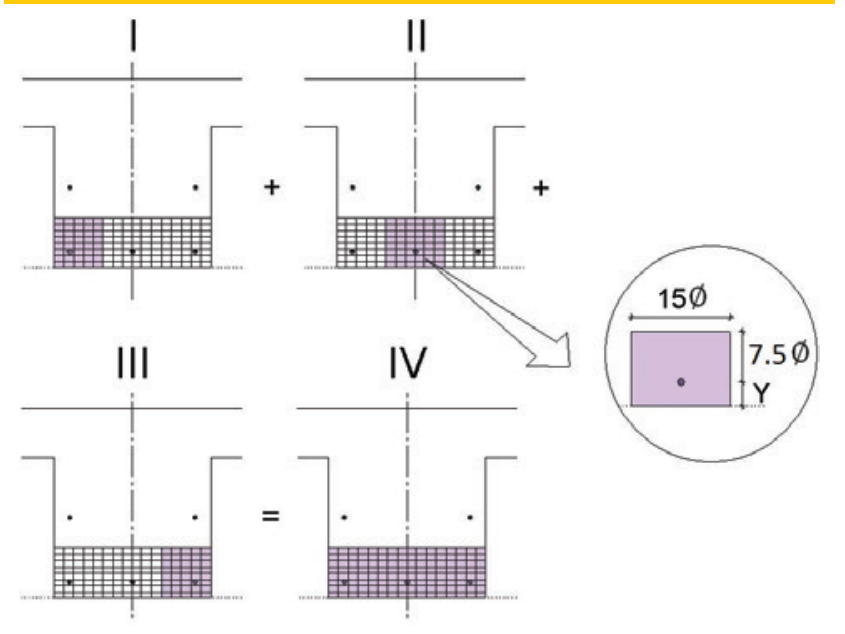

er are calculated by equations 10 and 11, respectively. Figure 6 shows a simplified flow chart of the SLS-W evaluation subroutine.

$\rho_{r}=\frac{A_{s}}{A_{c r}} \quad$ (10)

$$
\sigma_{s}^{C G}=\frac{\sum A_{s} \cdot \sigma_{s}}{\sum A_{s}}
$$

$$
w_{k 1}=\frac{\phi}{12 \cdot 5 \cdot \eta_{1}} \cdot \frac{\sigma_{s}^{C G}}{E_{s}} \cdot \frac{3 . \sigma_{s}^{C G}}{f_{c t m}}
$$

$$
w_{k 2}=\frac{\phi}{12.5 \cdot \eta_{1}} \cdot \frac{\sigma_{s}^{C G}}{E_{s}} \cdot\left(\frac{4}{\rho_{r}}+45\right)
$$

where:

$\phi$ : diameter of the tendon that protects the considered surrounding region;

$\eta_{1}$ : superficial frictional coefficient of the passive reinforcement; $E_{s}$ : modulus of elasticity of the passive reinforcement steel; $f_{c t m}$ : concrete average tensile strength (MPa);

The ultimate limit state (ULS) is related to the safety of the structure submitted to unfavorable combinations of actions predicted for its entire service life. In this evaluation, permanent and variable loads are increased and material strengths are decreased according to their respective weighting coefficients. Figure 7 shows the flow chart of ULS evaluation. Convergence occurs when ultimate calculation moment is lower or equal to the resistant moment. The resistant moment is obtained by adding incremental loads, in addition to live loading, until cracking.

\subsection{French norms}

In order to compare the results obtained with the Brazilian norm, the requirements of the French norm, BPEL 91 [11], were also examined. Table 3 presents the SLS evaluations required for members submitted to prestressing, using the same limit state conventions of NBR 6118 [10].

Tables 4 and 5 indicate the allowed stresses in concrete and steel, as determined by the French norm, for each prestressing level.

The prestressing reinforcement protection zone or cover zone

\section{Figure 6 - Flow chart of the routine verification SLS-W (Brazilian code specification)}

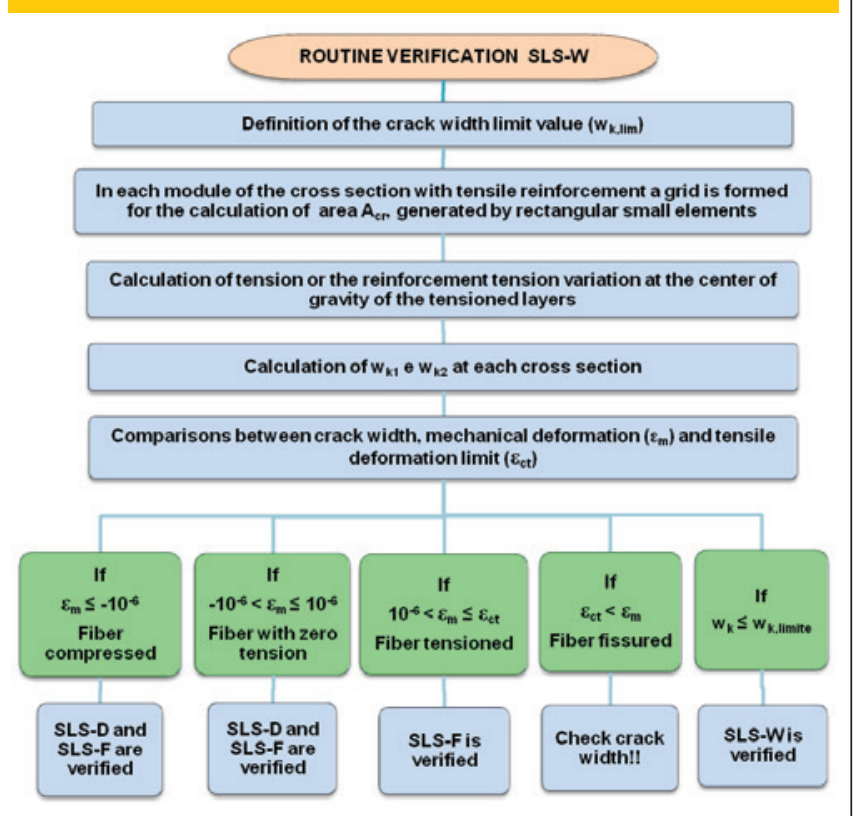


Figure 7 - Flow chart of the routine verification ULS (Brazilian code specification)

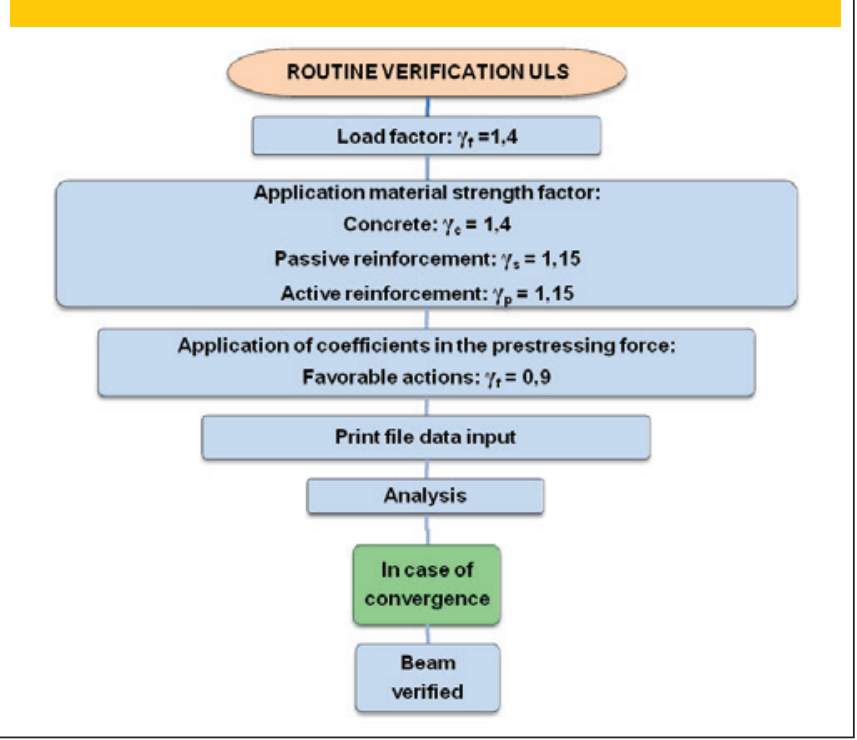

of a cross section is represented in Figure 8. This zone has the same center of gravity as the prestressing reinforcements, ensuring a minimal "c" protection cover. The value of cover "c" corresponds to the highest value between the tendon duct diameter and to the cover recommended for a specific class of environmental aggressive conditions. According to the French norm, this value corresponds to an environmental class equal to $3 \mathrm{~cm}$ in weather-protected sites, $4 \mathrm{~cm}$ in weather-exposed sites, and $5 \mathrm{~cm}$ in sites submitted to aggressive weather conditions (Thonier, [12]).

The evaluation during service of crack width essentially consists in the observation of passive and active reinforcement stress limits. If the passive reinforcement stress is lower or equal to the lowest value indicated in expression (15), and if active reinforcement stress variation between decompression state and final loading is below the limit value, which corresponds to $10 \%$ of maximal active reinforcement breaking strength relative to fatigue (expression 16), then the member is considered safe in terms of SLS-W. According to Thonier [12], if CA-50 steel is used in the passive reinforcement,

Table 3 - Verifications of Serviceability Limit State - French Code Specification (Thonier, (12))

\section{Load Combination}

Partial

Prestressing

Limited

Prestressing

Full Prestressing
Rare load combination

Frequent load combination

Quasi-permanent load combination

Rare load combination

Frequent load combination
Serviceability Limit State (SLS)

\section{SLS-W}

SLS-W (concrete cover zone*)

SLS-D (concrete cover zone*)

SLS-F $\left(\mathrm{f}_{\mathrm{tj}}\right.$ - concrete cover zone ${ }^{\star} ; 1.5 \mathrm{f}_{\mathrm{tj}}$ - others zones)

SLS-D (concrete cover zone*)

SLS-D

* Concrete cover zone: area of the section with a minimum protective concrete cover for active reinforcement.

Table 4 - Concrete allowable stresses - Serviceability Limit State - French Code Specification (Thonier, (12))

\begin{tabular}{|c|c|c|c|c|c|}
\hline & & & $\begin{array}{c}\text { Full } \\
\text { Prestressing }\end{array}$ & $\begin{array}{l}\text { Limited } \\
\text { Prestressing }\end{array}$ & $\begin{array}{l}\text { Partial } \\
\text { Prestressing }\end{array}$ \\
\hline & Quasi-permanent load combination & & & $0.5 \mathrm{f}_{\mathrm{ck}}$ & \\
\hline & Frequent load combination & & & $0.6 f_{c k}$ & \\
\hline Compression & Rare load combination & & & $0.6 f_{c k}$ & \\
\hline & Construction phase & & & $0.6 f_{c j}$ & \\
\hline \multirow{8}{*}{ Tension } & Quasi-permanent load combination & Concrete cover zone & 0 & 0 & 0 \\
\hline & & Others zones & 0 & $1.5 \mathrm{f}_{\mathrm{fij}}$ & - \\
\hline & Frequent load combination & Concrete cover zone & 0 & 0 & - \\
\hline & \multirow{3}{*}{ Rare load combination } & Others zones & 0 & $1.5 \mathrm{f}_{\mathrm{ti}}$ & - \\
\hline & & Concrete cover zone & 0 & $f_{i j}$ & - \\
\hline & & Others zones & 0 & $1.5 \mathrm{f}_{\mathrm{fij}}$ & - \\
\hline & \multirow[t]{2}{*}{ Construction phase } & Concrete cover zone & $0.7 \mathrm{f}_{\mathrm{ij}}$ & $0.7 \mathrm{f}_{\mathrm{ij}}$ & - \\
\hline & & Others zones & $0.7 \mathrm{f}_{\mathrm{tj}}$ & $1.5 \mathrm{f}_{\mathrm{fj}}$ & - \\
\hline
\end{tabular}


Table 5 - Steel allowable stresses - Serviceability Limit State - French Code Specification (Thonier, (12))

\begin{tabular}{|c|c|c|c|c|c|}
\hline & & & $\begin{array}{l}\text { Full } \\
\text { restressing }\end{array}$ & $\begin{array}{l}\text { Limited } \\
\text { Prestressing }\end{array}$ & $\begin{array}{c}\text { Partial } \\
\text { Prestressing }\end{array}$ \\
\hline \multicolumn{3}{|c|}{ Quasi-permanent load combination } & - & - & - \\
\hline \multirow{3}{*}{$\begin{array}{l}\text { Active } \\
\text { reinforcement }\end{array}$} & \multicolumn{2}{|l|}{ Frequent load combination } & - & - & $100 \mathrm{MPa}$ \\
\hline & \multicolumn{2}{|l|}{ Rare load combination } & - & - & $\Delta \sigma p<0.10 f_{p r g}$ \\
\hline & \multicolumn{2}{|l|}{ Construction phase } & - & - & $\Delta \sigma \mathrm{p}<0.10 f_{\mathrm{prg}}$ \\
\hline \multirow{4}{*}{$\begin{array}{l}\text { Passive } \\
\text { reinforcement }\end{array}$} & \multicolumn{2}{|c|}{ Quasi-permanent load combination } & - & - & - \\
\hline & Frequent load combination & Concrete cover zone & - & - & $0.35 f_{e}$ \\
\hline & \multirow{2}{*}{\multicolumn{2}{|c|}{ Rare load combination }} & - & - & - \\
\hline & & & - & $-\quad$ Min & $\eta\left(2 / 3 f_{e} ; 110 \cdot\left(\eta \cdot f_{t i}\right)^{1 / 2}\right)$ \\
\hline
\end{tabular}

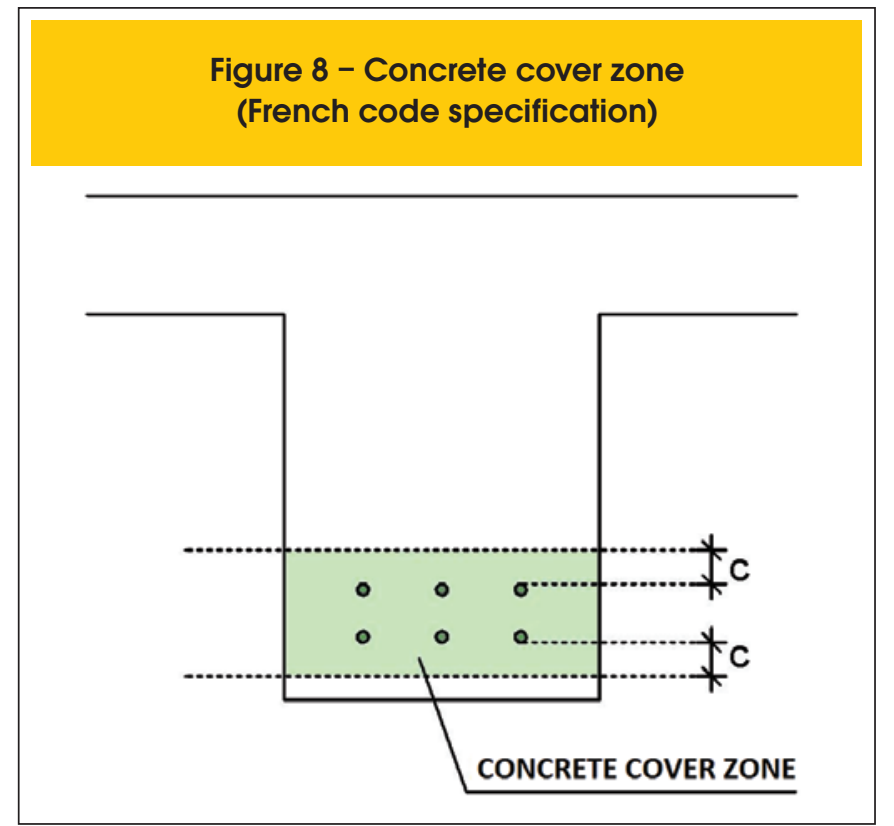

than the first part of stress limit $\left(2 / 3 . f_{\mathrm{e}}\right)$ test can be considered equal to $240 \mathrm{MPa}$. Figure 9 shows the flow chart of SLS-W evaluation.

$f_{t j}=0.06 f_{c k}+0.6$
$\sigma_{s} \leq \operatorname{Min}\left(\frac{2}{3} f_{e} ; 110 \sqrt{\eta \cdot f_{t j}}\right)$
$\Delta \sigma_{p} \leq 0.10 f_{p r g}$

where:

$f_{c k}$ : concrete characteristic compressive strength (MPa).

$f_{e}$ : elasticity limit of the passive reinforcement $(\mathrm{MPa})$;

$\eta$ : cracking coefficient ( $\eta=1.6$ for highly bonded reinforcement)

$f_{t j}$ : concrete characteristic tensile strength (MPa).

In the French norm, the study of ultimate limit state is performed as described in the Brazilian norm. Figure 10 shows the flow chart of the ULS evaluation model. At the end of the evaluation, the values of the ultimate moment should be compared with the resistant moment in order to determine if the beam is safe in terms of breaking.

\section{Analyzed structures}

In this article, the analyses of two beams removed from actual structures - one with bonded and the other with unbonded partial prestressing - are presented. Based on these specimens, crack opening service limit state and ultimate limit state were evaluated, and the results were analyzed according to both norms.

As a non-linear behavior was assumed for these actual specimens, the simplified diagrams recommended by the norms were not built. The strain values adopted for concrete compressive strength $\left(\varepsilon_{c 0}\right)$ and final strain $\left(\varepsilon_{\mathrm{cf}}\right)$ were $2 \%$ and $10 \%$, respectively.

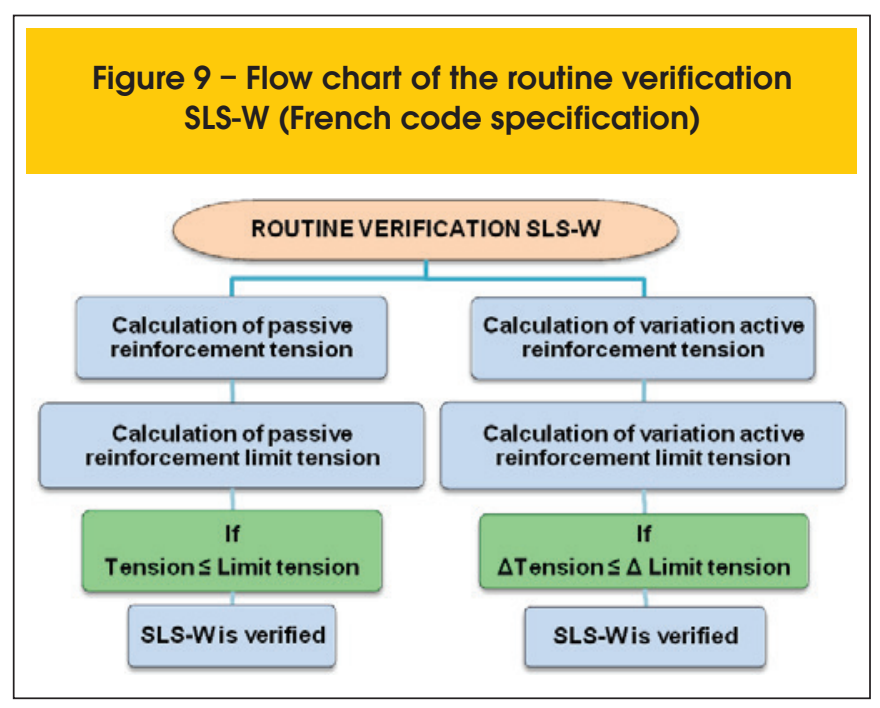




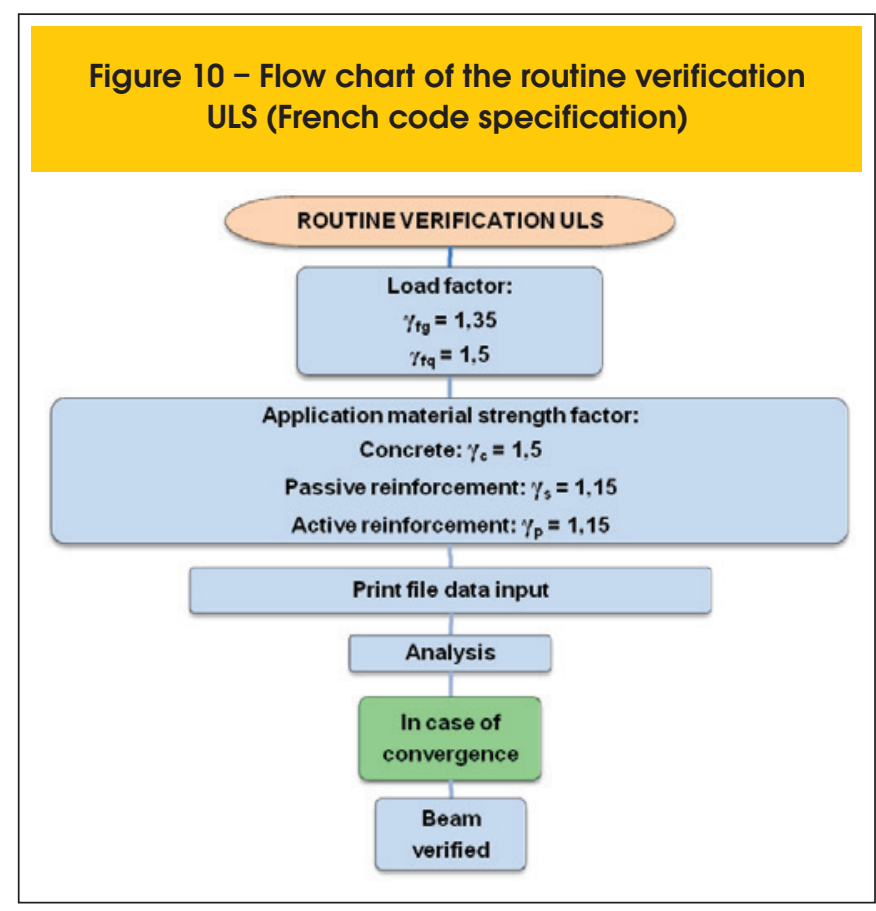

Characteristic compressive strength of the used concrete is $4 \mathrm{kN} / \mathrm{cm}^{2}$ and its tension strength was not considered. The value of the modulus of elasticity of concrete, calculated from $f_{c k}$, was $3542 \mathrm{kN} / \mathrm{cm}^{2}$ and $3762 \mathrm{kN} / \mathrm{cm}^{2}$ from SLS, for the Brazilian and French norms, respectively. Final concrete strength was estimated as $0.5 \mathrm{kN} / \mathrm{cm}^{2}$.

Passive reinforcement used CA-50 steel. The modulus of elasticity of the prestressed reinforcement is $21,000 \mathrm{kN} / \mathrm{cm}^{2}$ and its yield strain calculation is based on yield stress and modulus of elasticity. It is generally considered that stressed concrete has a brittle behavior.

Prestressed steel type CP-190RB with a modulus of elasticity equal to $19,500 \mathrm{kN} / \mathrm{cm}^{2}$ was used. Its yield stress, which corresponds to $90 \%$ of the prestressing steel strength $\left(f_{p u}=190 \mathrm{kN} / \mathrm{cm}^{2}\right)$, is equal to $171 \mathrm{kN} / \mathrm{cm}^{2}$. Conventional yield strain and prestressing steel breaking strain values were considered as 0.01 and 0.07 , respectively.

\subsection{Bonded partially prestressed beam}

The first situation analyzed pertains to a simply supported bonded partially prestressed beam used in the roof of the Feevale theater, built in front of Feevale University campus, Novo Hamburgo, state

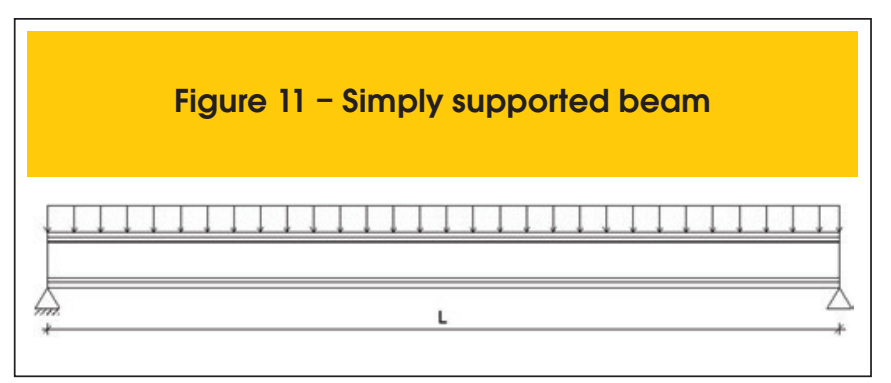

Figure 12 - Beam cross-section $(\mathrm{cm})$

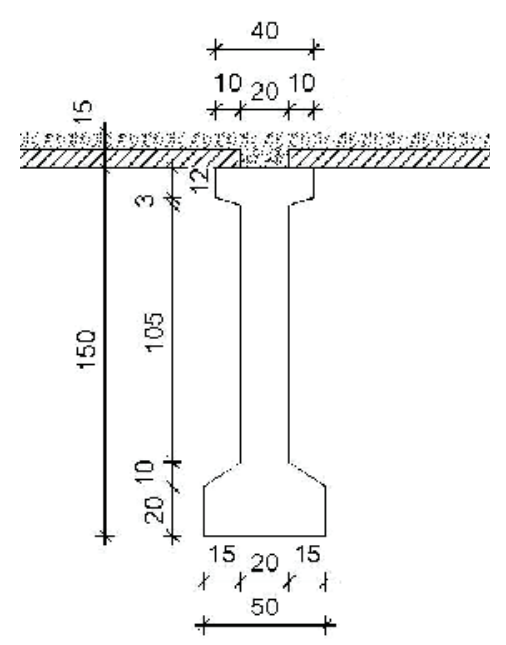

Figure 13 - F.E. modeding of the beam

\begin{tabular}{|c|c|c|}
\hline NODE 1 & 35 SECTIONS & NODE 2 \\
\hline Am & ELEMENT 1 & $\triangle$ \\
\hline MODULE 1 MODULE 2 & MODULE 3 & MODULE 4 \\
\hline
\end{tabular}

of Rio Grande do Sul, Brazil [13]. The precast beam has a 31.8 span length and is submitted to permanent $(\mathrm{g}=15.6 \mathrm{kN} / \mathrm{m})$ and variable $(q=6.9 \mathrm{kN} / \mathrm{m}$ ) loadings distributed along its length, as shown the diagram in Figure 11.

Figure 12 present the beam's cross section, initially consisting of a $1.50-\mathrm{m}$ high precast section I with passive and active reinforcements. After the beam was set on the lateral foundations, the upper compression flange was added by placing concrete of the cover slab, which was $15-\mathrm{cm}$ thick and 3.4-m wide (between beam axes). The beam span was modeled using a hybrid single finite element linked by nodes 1 and 2, as shown in Figure 13. The element was divided into 35 cross sections distributed in five integration modules along the element in order to comply with the geometry of the straight section of the prestressing tendons.

Total beam cross section, section I and compression flange were divided into 18 horizontal planes and in six modules along its height, as shown in Figure 14. The horizontal planes are placed at the ends and at the center of each module, overlapping where the modules meet. The cross section of section I consists of five integration modules with two layers each, and the flange was modeled as a single module consisting of two layers. The numerical integration rule of Gauss-Lobatto was chosen because it is more accurate that the Simpson's rule and because it is recommended when the integration points are not evenly distributed. 
Figure 14 - Definition of the cross-section modules

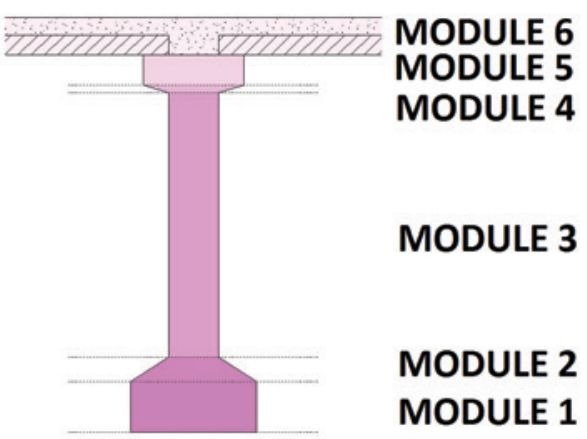

Passive reinforcement tendons were distributed in 13 layers, as shown in Figure 15, with a $2.5-\mathrm{cm}$ cover. Table 6 presents the characteristics of each passive reinforcement layer, including its relative position, diameter, number of tendons, section, and date. The bonded prestressing tendons have a straight section and are distributed in three layers, as shown in Figure 16. Table 7 shows the characteristics of location, diameter, number of bars, reinforcement section, and prestressing date of each layer of the active reinforcement. Initial stress value for the prestressing tendons was $152 \mathrm{kN} / \mathrm{cm}^{2}$.

Table 8 presents the loading cases used for SLS evaluation. The applied loading was calculated according to the load combination required for service evaluation as determined in each norm. In SLS-W evaluation, a distributed load of $18.4 \mathrm{kN} / \mathrm{m}$ (frequent combination) was considered for the Brazilian norm and of $22.5 \mathrm{kN} / \mathrm{m}$ (rare combination) for the French norm.

According to Table 8 , the member was analyzed on day 28 , considering prestressing only of the precast section I. The second load

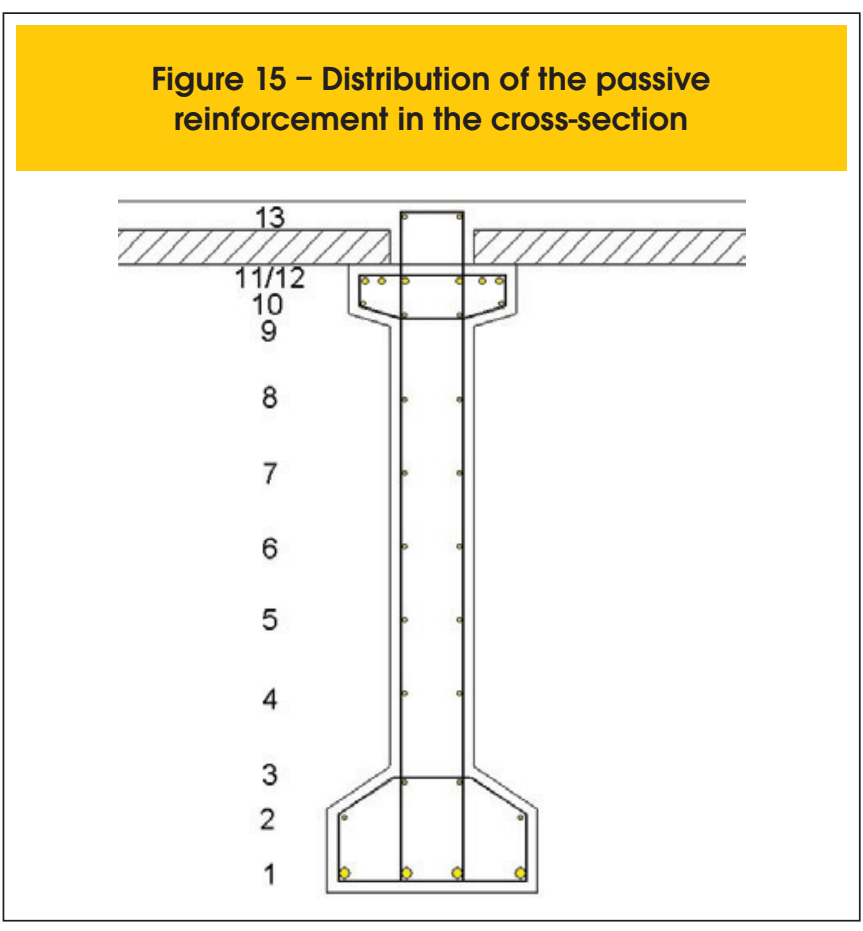

case is applied on day 29 , when the compression flange was added to the upper part of the section. Having the total section working monolithically, the permanent loading portion (g) was added, corresponding to the non-reduced portion of the total structure load. Between days 29 and 10,000, the effects of yield, shrinkage, and relaxation on the total section were calculated. After the analysis of structural behavior relative to time, the last loading portion was added on day 10,000 , corresponding to the reduced variable load (q) along the element's sections. Five load increments were estimated for cases 1, 2, 3, and 5.

After SLS-W was evaluated according to the Brazilian and French norms, results were analyzed in a post-processing stage. Input

Table 6 - Characteristics of the passive reinforcement layers

\begin{tabular}{|cccccc|}
\hline Layer & Height $(\mathrm{cm})$ & $(\mathrm{mm})$ & Number of bars & Area $\left(\mathrm{cm}^{2}\right)$ & Date (days) \\
\hline 1 & 4.5 & 25 & 4 & 19.63 & 28 \\
2 & 20 & 8 & 2 & 1.01 & 28 \\
3 & 30 & 8 & 2 & 1.01 & 28 \\
4 & 50 & 8 & 2 & 1.01 & 28 \\
5 & 70 & 8 & 2 & 1.01 & 28 \\
6 & 85 & 8 & 2 & 1.01 & 28 \\
7 & 100 & 8 & 2 & 1.01 & 28 \\
8 & 120 & 8 & 2 & 1.01 & 28 \\
9 & 135 & 8 & 2 & 1.01 & 28 \\
10 & 140 & 8 & 2 & 1.01 & 28 \\
11 & 145 & 16 & 6 & 12.06 & 28 \\
12 & 145 & 12.5 & 4 & 4.91 & 28 \\
13 & 160 & 10 & 2 & 1.57 & 29 \\
\hline
\end{tabular}




\section{Figure 16 - Distribution of active reinforcement layers along the element}

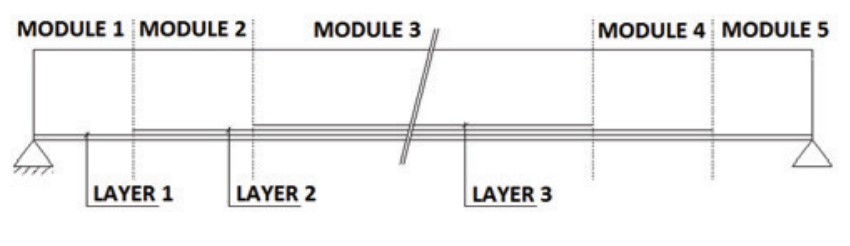

data, such as material properties, are shown in Figure 17 and were common to both evaluations, except for the values of the modulus of elasticity of concrete.

Figure 19 presents normal stress caused by prestressing and shear strength graphs resulting from frequent loading (Brazilian norm), relative to the values presented in Figure 18. Because tendons are straight, prestressing does not generate stresses relative to shear strength.

Figure 20 shows first the flexural moment relative to loading (frequent combination) and applied prestressing graphs, and then a graph of the total moment, representing the sum of the first two graphs. In the normal stress, prestressing moment and total moment graphs, the "steps" caused by the use of prestressing tendons with different lengths are clearly seen. In this evaluation, based on flexural moment values, it is observed that prestressing strength absorbs almost $72 \%$ of total loading relative to frequent combination.

Figure 21 presents a table with the cracking width values of all sections, as evaluated according to the Brazilian norm, with $w_{k}$ as the lowest value between $w_{k 1}$ and $w_{k 2}$. Figure 22 shows the strain graph of each passive reinforcement layer and the limit strain recommended by the French norm.

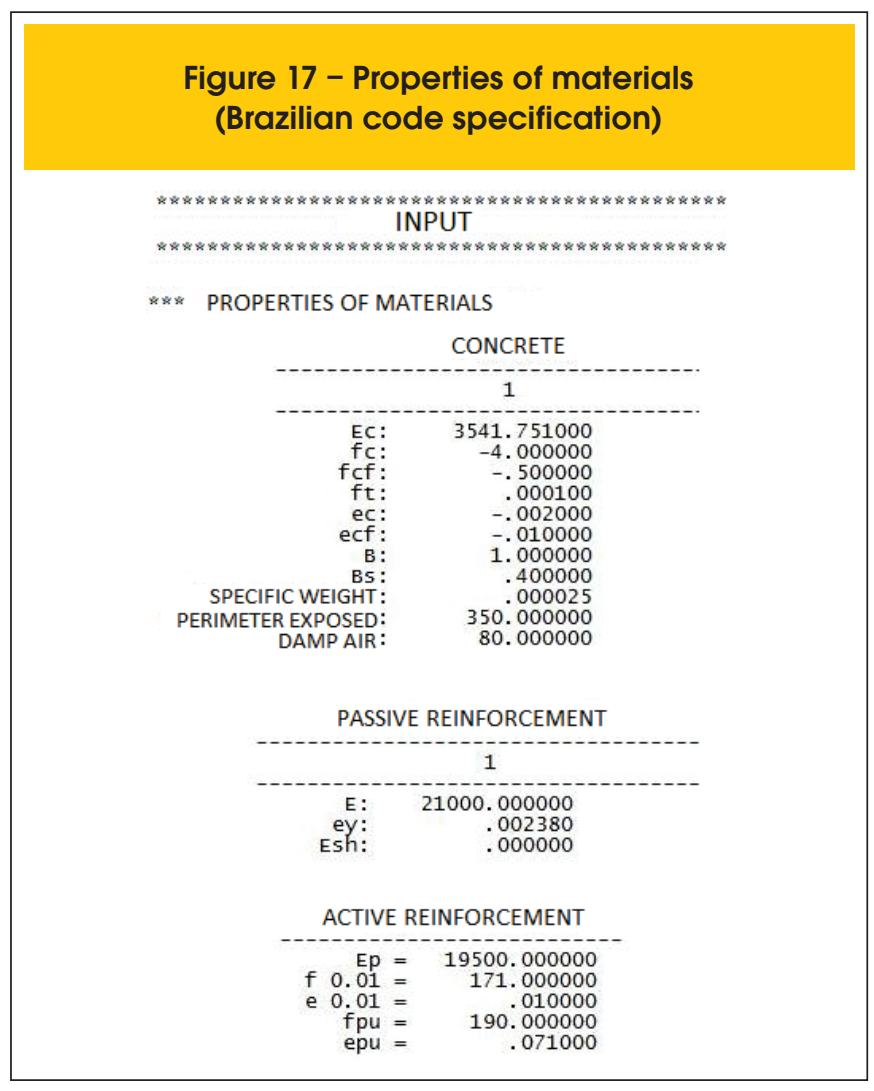

In the SLS-W analysis relative to the Brazilian norm, crack width values were calculated only for the four sections located at the ends of the beam (sections 1, 2, 34, and 35). In the modules of these sections, where the passive reinforcement layer is stressed, a grid with small rectangles was generated to determine the $A_{c r}$

Table 7 - Characteristics of the active reinforcement layers

\begin{tabular}{|cccccc|}
\hline Layer & Height $(\mathrm{cm})$ & $\emptyset(\mathrm{mm})$ & Number of caloles & Area $\left(\mathrm{cm}^{2}\right)$ & Date (days) \\
\hline 1 & 9 & 15.2 & 8 & 11.48 & 28 \\
2 & 14 & 15.2 & 6 & 8.61 & 28 \\
3 & 19 & 15.2 & 6 & 8.61 & 28 \\
\hline
\end{tabular}

Table 8 - Load cases for verifications of Serviceability Limit State

\begin{tabular}{|c|c|c|c|}
\hline \multicolumn{4}{|c|}{ Load cases } \\
\hline Cases & Load cases & Initial date (days) & Final date (days) \\
\hline 1 & Weigth I shaped + prestressing & 28 & 28 \\
\hline 2 & Weigth table & 29 & 29 \\
\hline 3 & Permanent load (g) & 29 & 29 \\
\hline 4 & Time effects & 29 & 10,000 \\
\hline 5 & Variable load (q) & 10,000 & 10,000 \\
\hline
\end{tabular}


Figure 18 - Cross-sections forces ( $\mathrm{kN}, \mathrm{cm}$ ) - Brazilian code specification (frequent load combination)

\begin{tabular}{|c|c|c|c|c|c|c|c|c|c|c|}
\hline \multirow[b]{2}{*}{ SEC. } & \multirow[b]{2}{*}{ pos. } & \multicolumn{3}{|c|}{ AXIAL FORCE } & \multicolumn{3}{|c|}{ SHEAR FORCE } & \multicolumn{3}{|c|}{ BENDING MOMENT } \\
\hline & & TOTAL & PRESTRESSING & VARIABLE & TOTAL & $\begin{array}{l}\text { PRESTRESSING } \\
\end{array}$ & VARIABLE & TOTAL & PRES ISO & PRES HIPER LOAD \\
\hline $\begin{array}{r}1 \\
2 \\
3 \\
4 \\
5 \\
6 \\
7 \\
8 \\
8 \\
9 \\
10 \\
11 \\
12 \\
13 \\
14 \\
15 \\
16 \\
17 \\
18 \\
20 \\
21 \\
22 \\
23 \\
24 \\
25 \\
26 \\
27 \\
28 \\
29 \\
30 \\
31 \\
32 \\
33 \\
34 \\
35\end{array}$ & $\begin{array}{r}.00 \\
21.22 \\
66.39 \\
125.00 \\
183.61 \\
228.78 \\
250.00 \\
250.00 \\
275.47 \\
329.67 \\
400.00 \\
470.33 \\
524.53 \\
550.00 \\
550.00 \\
726.57 \\
1102.40 \\
1590.00 \\
20077.60 \\
2453.43 \\
2630.00 \\
2630.00 \\
2655.47 \\
2709.67 \\
2780.00 \\
2850.33 \\
2904.53 \\
2930.00 \\
2930.00 \\
2951.22 \\
2996.39 \\
3055.00 \\
3113.61 \\
3158.78 \\
3180.00\end{array}$ & $\begin{array}{l}-1358.50 \\
-1364.79 \\
-1377.44 \\
-1393.29 \\
-1408.50 \\
-1419.77 \\
-1424.98 \\
-2369.27 \\
-2379.47 \\
-2400.48 \\
-2426.36 \\
-2450.15 \\
-2456.82 \\
-2474.82 \\
-24372.17 \\
-3439.17 \\
-3535.00 \\
-3580.52 \\
-35355.60 \\
-3439.00 \\
-3372.17 \\
-2474.29 \\
-2466.82 \\
-2450.15 \\
-2426.36 \\
-2400.48 \\
-2379.47 \\
-2369.27 \\
-1424.98 \\
-1419.77 \\
-1408.50 \\
-1393.29 \\
-1377.44 \\
-1364.79 \\
-1358.50\end{array}$ & $\begin{array}{l}-1358.50 \\
-1364.79 \\
-1377.44 \\
-1393.29 \\
-1408.50 \\
-1419.77 \\
-1424.98 \\
-2369.27 \\
-2379.47 \\
-2400.48 \\
-2426.36 \\
-2450.15 \\
-2466.82 \\
-2474.29 \\
-3374.17 \\
-3439.17 \\
-3535.60 \\
-3580.52 \\
-3535.60 \\
-3439.00 \\
-3372.17 \\
-2474.29 \\
-2466.82 \\
-2450.15 \\
-2426.36 \\
-2400.48 \\
-2379.47 \\
-2369.27 \\
-1424.98 \\
-1419.77 \\
-1408.50 \\
-1393.29 \\
-1377.44 \\
-1364.79 \\
-1358.50\end{array}$ & $\begin{array}{l}.00 \\
000 \\
000 \\
000 \\
000 \\
000 \\
000 \\
000 \\
000 \\
000 \\
000 \\
000 \\
000 \\
000 \\
000 \\
000 \\
000 \\
000 \\
000 \\
000 \\
000 \\
000 \\
000 \\
000 \\
000 \\
000 \\
000 \\
000 \\
000 \\
000\end{array}$ & $\begin{array}{l}-654.44 \\
-645.71 \\
-627.12 \\
-602.99 \\
-578.87 \\
-560.28 \\
-551.54 \\
-551.54 \\
-541.06 \\
-518.06 \\
-489.80 \\
-460.86 \\
-438.56 \\
-428.06 \\
-428.06 \\
-355.06 \\
-300.39 \\
200.00 \\
200.70 \\
355.39 \\
428.06 \\
428.06 \\
438.55 \\
460.86 \\
489.80 \\
518.75 \\
541.06 \\
551.54 \\
551.54 \\
560.28 \\
578.87 \\
602.99 \\
627.12 \\
645.71 \\
654.44\end{array}$ & 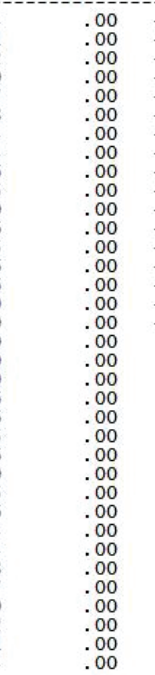 & 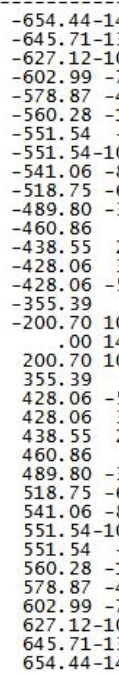 & 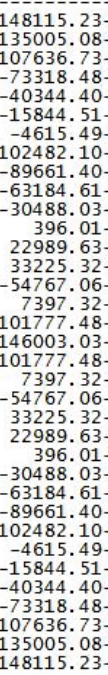 & 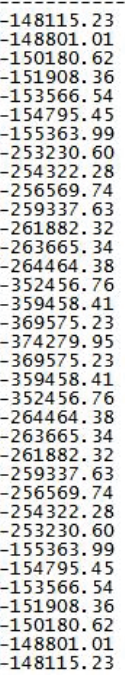 & 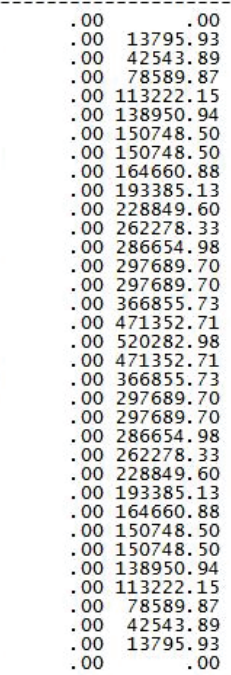 \\
\hline
\end{tabular}

\section{Figure 19 - Axial and Shear forces - Brazilian code} specification (frequent load combination)

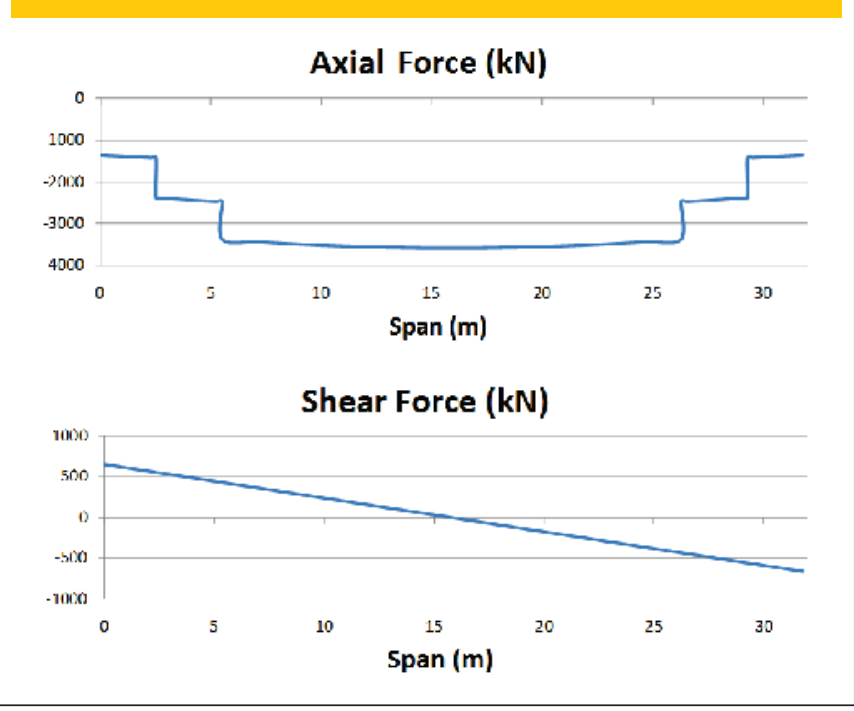

area required for $w_{k}$ calculation. The maximal crack width value found in the analysis $\left(w_{k}=0.000125 \mathrm{~mm}\right)$ was lower than that established by the Brazilian norm ( $w_{k \text {.lim }}=0.2 \mathrm{~mm}$ ), thereby ensuring the member safety regarding SLS-W.

In the French norm, SLS-W is evaluated only by comparison of reinforcement stresses, and therefore, the discretization of each stressed reinforcement module in an extremely refined grid is not required. Analyzing the strain graphs of each passive reinforcement layer, it is observed that layers $7,8,9,10$, and 11 present tensile stresses in the sections located at the beam's ends. In these sec- tions, reinforcement layer tensile stress was compared with limit stress. As the corresponding limit strain is equal to $1.143 \%$, that is, much higher than the obtained maximal strain $(0.538 \%$ ), beam safety is ensured relative to SLS-W.

Figures 23 and 24 show the cracking tables calculated according to the Brazilian and French norms, respectively. It is observed that the central sections are not cracked. Crack width was determined for the upper edge of the regions close to the foundations.

Based on the cracking tables of this example, it was found that most sections were still completely compressed at the end of SLS evaluation. In addition, according to both Brazilian and French norms, most lower and central fibers were still compressed (-1), differently from the upper fibers, close to the foundations, which already presented some cracking (2).

Figure 25 shows a photograph of the assembly of the cover beams in the structure of Feevale theater in Novo Hamburgo, RS, Brazil. The beams arrived at the site with an initial hogging of approximately $4 \mathrm{~cm}$, and sagging was virtually null after total load was applied.

After ULS verification was analyzed according to the Brazilian and French norms, ultimate moment values were compared with resistant moment values. According to the criteria of the Brazilian norm, the resistant moment $(9,460 \mathrm{kN} . \mathrm{m})$ was compared with ultimate moment $(8,015 \mathrm{kN} . \mathrm{m})$ and an additional safety factor equal to 1.18 was obtained for breaking. When using the French norm, the resistant moment value $(9,896 \mathrm{kN}$.m) was 1.26 times higher than the ultimate moment $(7,860 \mathrm{kN} . \mathrm{m})$, which is lower than that obtained with the Brazilian norm due to different load increment coefficients. As in both cases ultimate moment was lower than the resistant moment, element safety regarding rupture is ensured.

\subsection{Unbonded partially prestressed beam}

In order to illustrate the use of unbonded reinforcement in evalu- 
Figure 20 - Bending Moment - Brazilian code specification (frequent load combination)

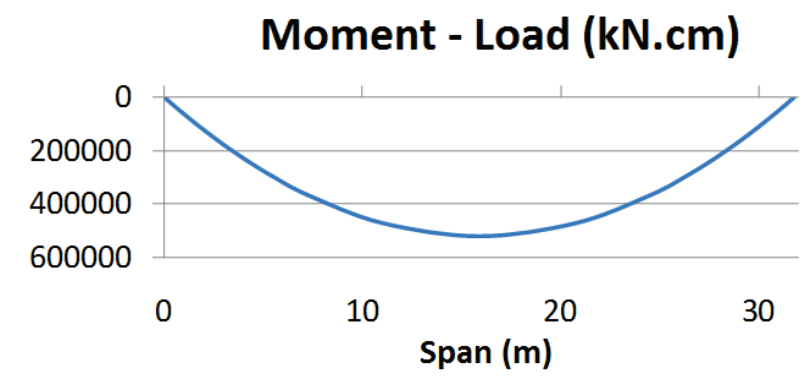

\section{Moment - Prestressing (kN.cm)}

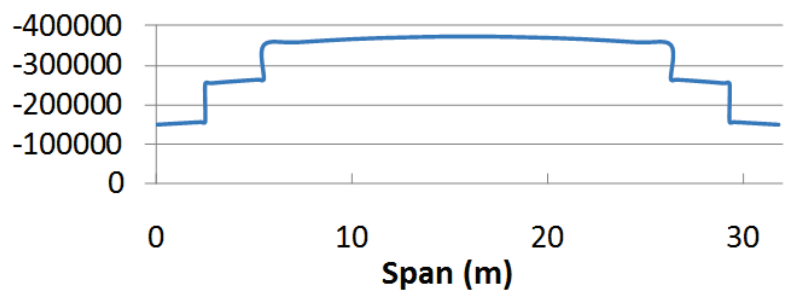

\section{Moment - Total (kN.cm)}

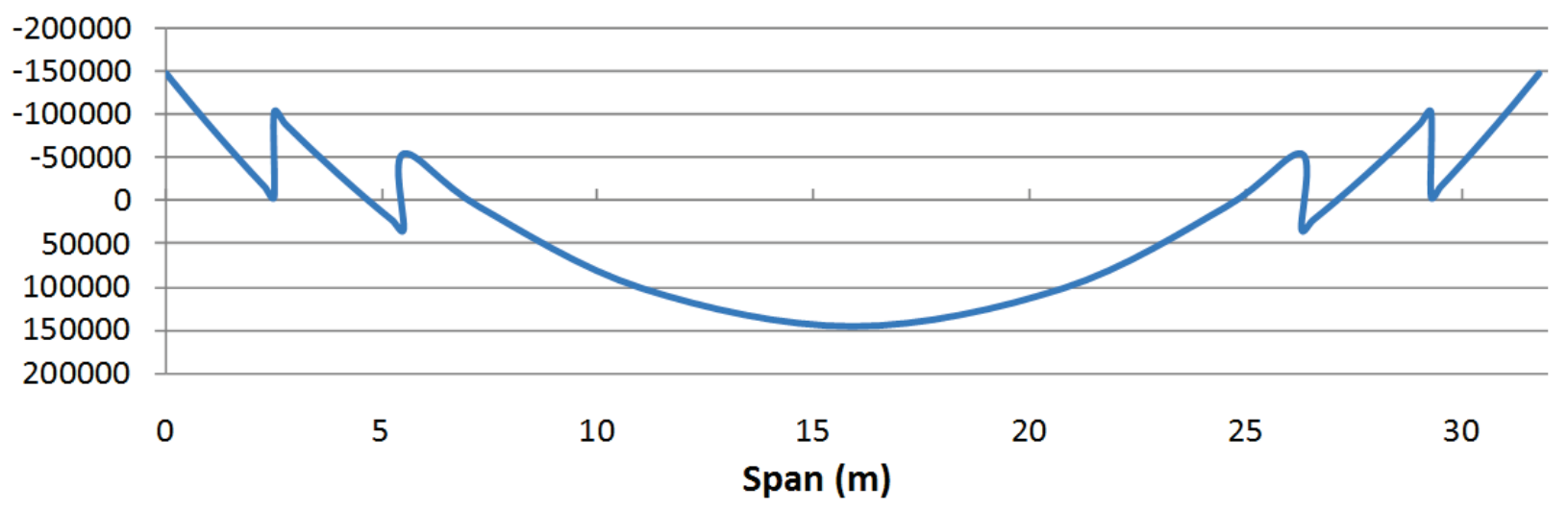

\begin{tabular}{|c|c|c|c|}
\hline \multicolumn{4}{|c|}{$\begin{array}{l}\text { Figure } 21 \text { - Crack width along the } \\
\text { sections (mm) - Brazilian code } \\
\text { cification (frequent load combination) }\end{array}$} \\
\hline \multicolumn{4}{|c|}{ ** CRACK WIDTH - WK (mm) } \\
\hline \multicolumn{4}{|c|}{ ** LIMIT CRACK WIDTH = $\quad .200$} \\
\hline SECTION & WK1 & WK2 & wK \\
\hline $\begin{array}{r}1 \\
1 \\
3 \\
4 \\
5 \\
5 \\
6 \\
7 \\
8 \\
9 \\
10 \\
11 \\
12 \\
13 \\
14 \\
15 \\
16 \\
17 \\
18 \\
19 \\
20 \\
21 \\
22 \\
23 \\
24 \\
25 \\
26 \\
27 \\
28 \\
29 \\
30 \\
31 \\
32 \\
33 \\
34 \\
35\end{array}$ & $\begin{array}{l}.0001249864 \\
.0000003583 \\
.0000000000 \\
.0000000000 \\
.0000000000 \\
.0000000000 \\
.0000000000 \\
.0000000000 \\
.0000000000 \\
.0000000000 \\
.0000000000 \\
.0000000000 \\
.0000000000 \\
.0000000000 \\
.0000000000 \\
.0000000000 \\
.0000000000 \\
.0000000000 \\
.0000000000 \\
.0000000000 \\
.0000000000 \\
.0000000000 \\
.0000000000 \\
.0000000000 \\
.0000000000 \\
.0000000000 \\
.0000000000 \\
.0000000000 \\
.0000000000 \\
.0000000000 \\
.0000000000 \\
.0000000000 \\
.0000000000 \\
.0000003583 \\
.0001249864\end{array}$ & $\begin{array}{l}.0319561144 \\
.0018502580 \\
.0000000000 \\
.0000000000 \\
.0000000000 \\
.0000000000 \\
.0000000000 \\
.0000000000 \\
.0000000000 \\
.0000000000 \\
.0000000000 \\
.0000000000 \\
.0000000000 \\
.0000000000 \\
.0000000000 \\
.0000000000 \\
.0000000000 \\
.0000000000 \\
.0000000000 \\
.0000000000 \\
.0000000000 \\
.0000000000 \\
.0000000000 \\
.0000000000 \\
.0000000000 \\
.0000000000 \\
.0000000000 \\
.0000000000 \\
.0000000000 \\
.0000000000 \\
.0000000000 \\
.0000000000 \\
.0000000000 \\
.0018502580 \\
.0319561144\end{array}$ & $\begin{array}{l}.0001249864 \\
.0000003583 \\
.0000000000 \\
.0000000000 \\
.00000000000 \\
.0000000000 \\
.0000000000 \\
.0000000000 \\
.0000000000 \\
.0000000000 \\
.0000000000 \\
.0000000000 \\
.0000000000 \\
.0000000000 \\
.0000000000 \\
.0000000000 \\
.0000000000 \\
.0000000000 \\
.0000000000 \\
.0000000000 \\
.0000000000 \\
.0000000000 \\
.0000000000 \\
.0000000000 \\
.0000000000 \\
.0000000000 \\
.0000000000 \\
.0000000000 \\
.0000000000 \\
.0000000000 \\
.0000000000 \\
.0000000000 \\
.0000000000 \\
.0000003583 \\
.0001249864\end{array}$ \\
\hline
\end{tabular}

ation routines, we present here the example of an unbonded partially prestressed simply supported beam, as shown in the diagram of Figure 26. This structure was used in the extension of Estação Shopping Mall, in Curitiba, state of Paraná, Brazil. The beam, locally cast, has a span length of $12.92 \mathrm{~m}$ and supports permanent $(\mathrm{g}=10 \mathrm{kN} / \mathrm{m}$, not considering its own weight) and variable $(q=23 \mathrm{kN} / \mathrm{m})$ loadings distributed along its length. Moments $M_{1}=468 \mathrm{kN} \cdot \mathrm{m}$ and $\mathrm{M}_{2}=526 \mathrm{kN} \cdot \mathrm{m}$ were considered in each beam end. These moments, which take into account

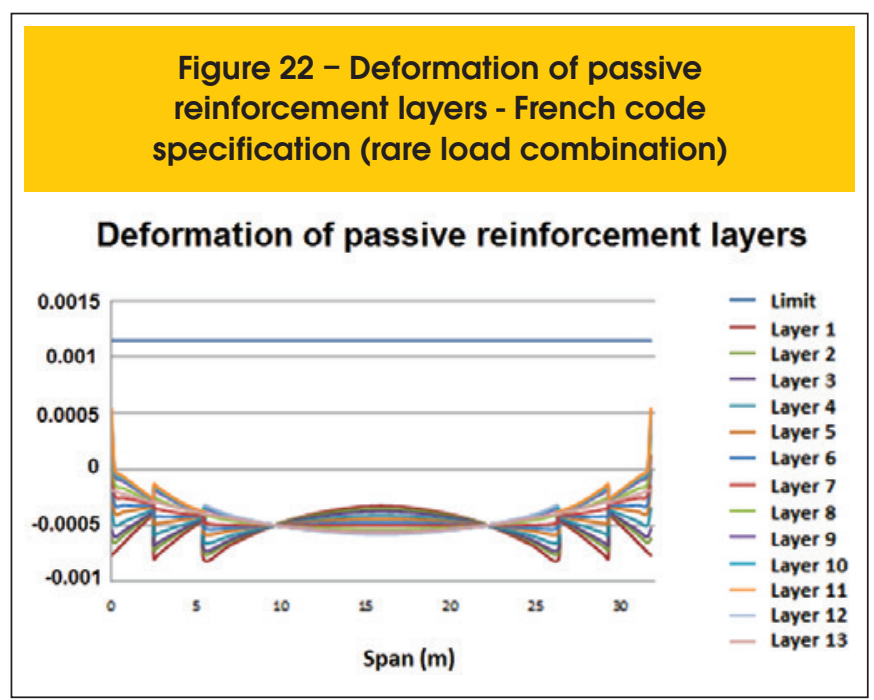


Figure 23 - Cracking table - Brazilian code specification (frequent load combination)

VERIFICATION - BRAZILIAN CODE SPECIFICATION - NBR6118

PRESTRESSED CONCRETE

PARTIAL PRESTRESSING - NIVEL 1

FREQUENT COMBINATION LOAD

NONLINEAR BEHAVIOR OF CONCRETE

VERIFICATION OF ELS-W - PASSIVE REINFORCEMENT

$9=$ LAYER NOT CONSIDERED IN THE ANALYSIS

$2=$ LAYER CRACKING

1 = LAYER TENSIONED

$0=$ LAYER WITH ZERO STRAIN

$-1=$ LAYER COMPRESSED

$-2=$ LIMIT COMPRESSION EXCEEDED

ELEMENT 1

LAYER SECTIONS

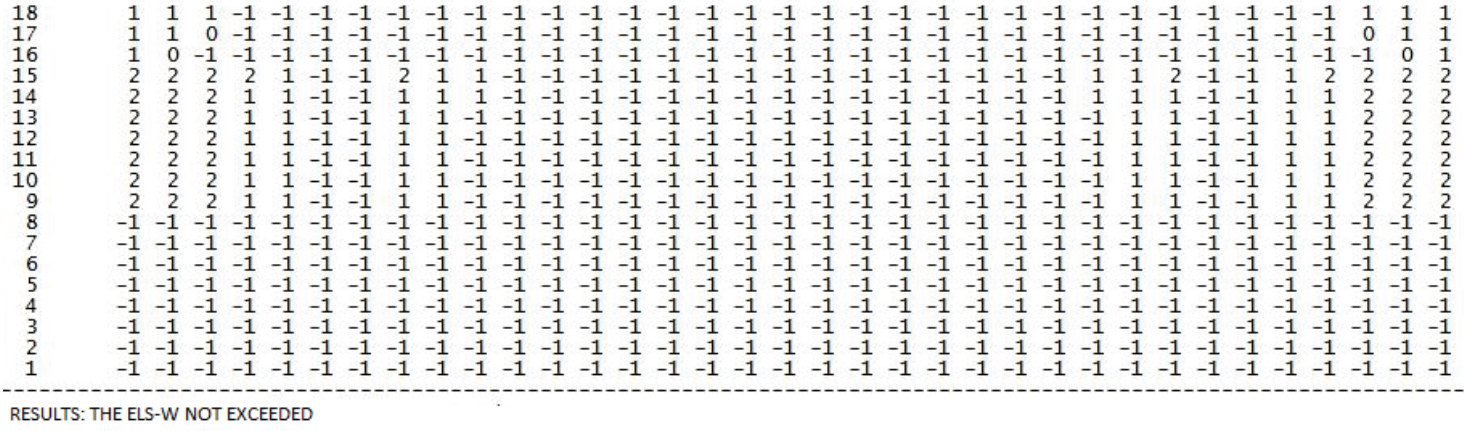

Figure 24 - Cracking table - French code specification (rare load combination)

VERIFICATION - FRENCH CODE SPECIFICATION - BPEL91

PRESTRESSED CONCRETE

PARTIAL PRESTRESSING - CLASSE III

RARE COMBINATION LOAD

NONLINEAR BEHAVIOR OF CONCRETE

VERIFICATION OF ELS-W - PASSIVE REINFORCEMENT

9 = LAYER NOT CONSIDERED IN THE ANALYSIS

$2=$ LAYER CRACKING

$1=$ LAYER TENSIONED

$0=$ LAYER WITH ZERO STRAIN

$-1=$ LAYER COMPRESSED

$-2=$ LIMIT COMPRESSION EXCEEDED

ELEMENT 1

LAYER SECTION

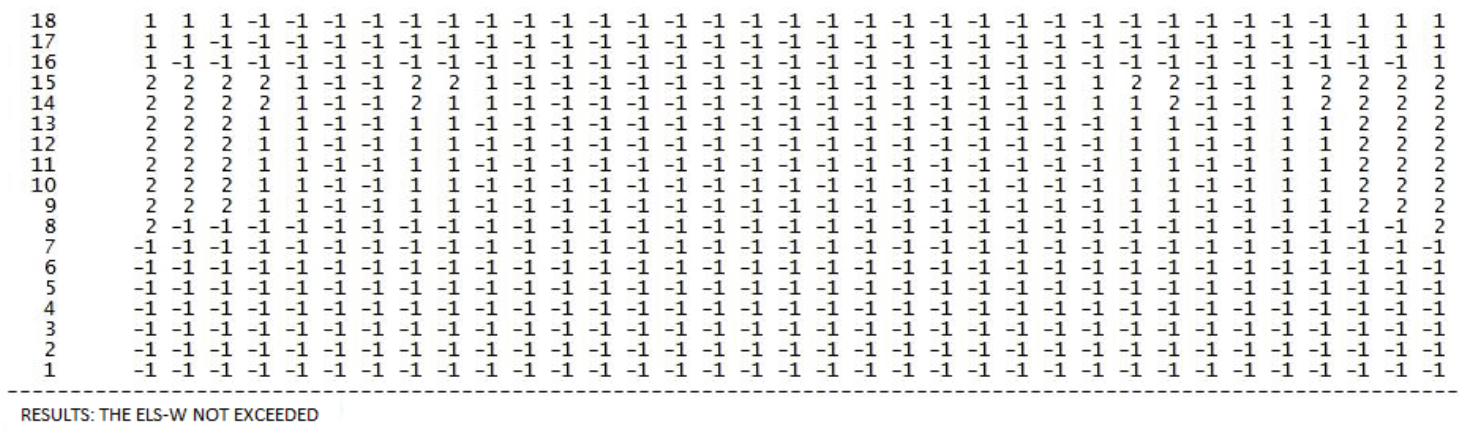


the sum of permanent moment (30\% of the total moment) with variable moment $(70 \%$ of the total moment), were used as a calculation artifact to consider the partial incasing of the beam
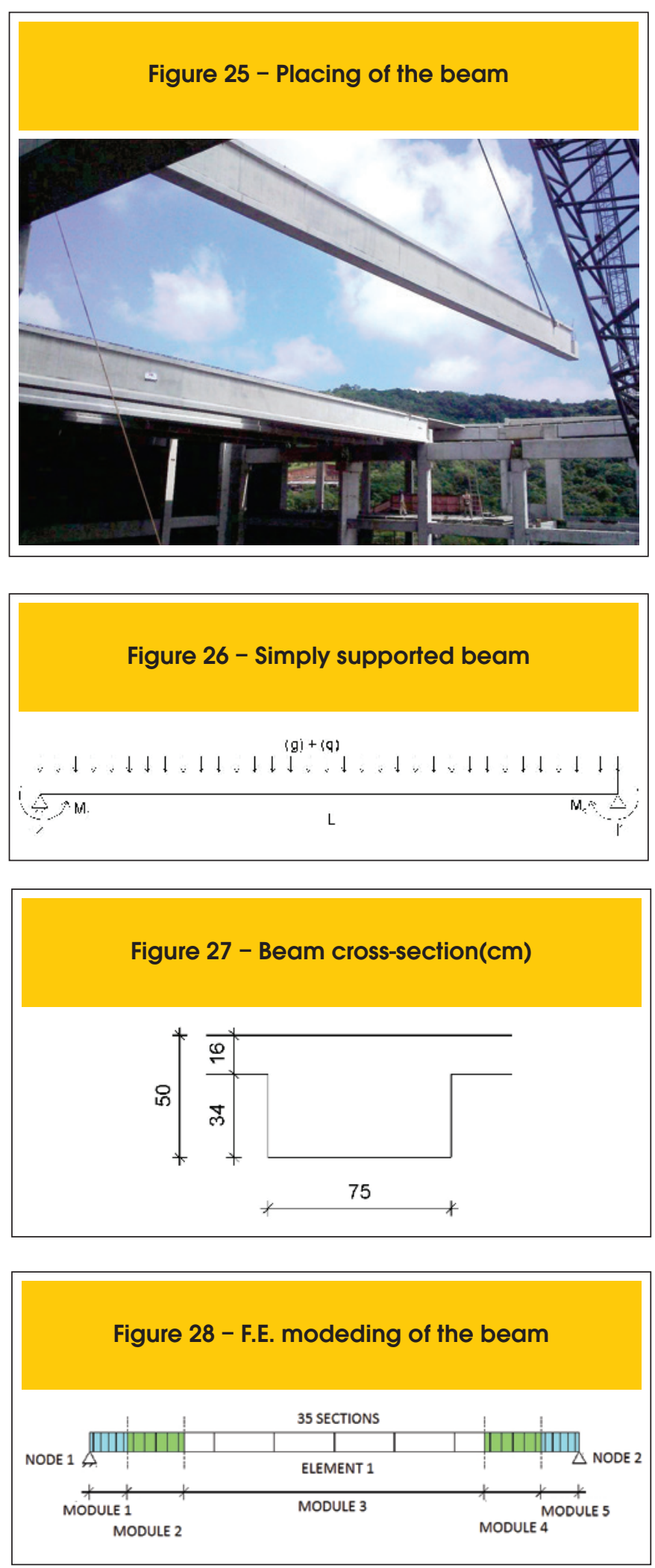

ends in columns and were obtained by the global analysis of the structure.

Figure 27 shows the beam's cross section, consisting of a locally cast section $T$, being $50 \mathrm{~cm}$ high and $75 \mathrm{~cm}$ wide at the lower foundation and containing passive and active reinforcements. The upper compressive flange, belonging to the slab, is $16 \mathrm{~cm}$ thick and $275 \mathrm{~cm}$ wide, considering $1 \mathrm{~m}$ of slab on each side of the section.

The beam span was modeled using a hybrid single finite element linked by nodes 1 and 2, as shown in Figure 28. The element was divided into 35 cross sections distributed in five integration modules along the element in order to take the location of the passive reinforcement layers into consideration.

The cross section of the beam was divided into 18 horizontal planes and in two modules along its height, as shown in Figure 29. Modules 1 and 2 of the cross section consist of eight layers each. Layers were $4.25 \mathrm{~cm}$ and $2 \mathrm{~cm}$ thick in modules 1 and 2 , respectively. As in the previous example, the numerical integration rule of Gauss-Lobatto was chosen because it is more accurate.

Passive reinforcement tendons were distributed in six layers, as shown in Figure 30, with a 2.0-cm cover, as determined in the design. Table 9 presents the characteristics of each passive reinforcement layer, including their position, diameter, number of tendons, reinforcement section, and date.

The ten unbonded prestressing tendons present a parabolic profile and are distributed in a single layer, as shown in Figure 31. Table 10 presents the characteristics of location, diameter, number of tendons, reinforcement section, and date of active reinforce-
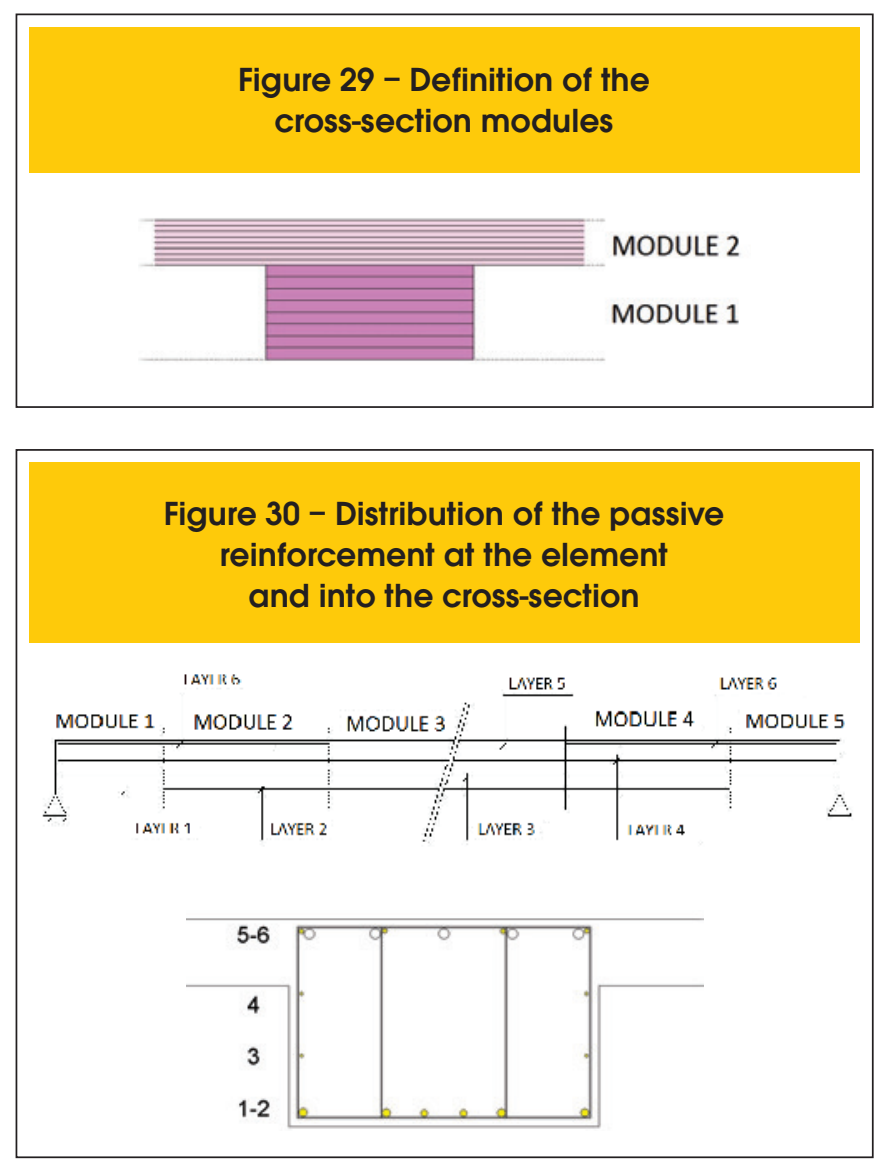
Table 9 - Characteristics of the passive reinforcement layers

\begin{tabular}{|cccccc} 
Layer & Height $(\mathrm{cm})$ & $\theta(\mathrm{mm})$ & Number of bars & Area $\left(\mathrm{cm}^{2}\right)$ & Date (days) \\
\hline 1 & 3.8 & 20 & 4 & 12.57 & 28 \\
2 & 3.8 & 16 & 2 & 4.02 & 28 \\
3 & 17 & 6.3 & 2 & 0.62 & 28 \\
4 & 34 & 6.3 & 2 & 0.62 & 28 \\
5 & 46 & 25 & 6 & 3.14 & 28 \\
6 & 46 & 10 & 4 & 29.45 & 28 \\
\hline
\end{tabular}

Table 10 - Characteristics of the active reinforcement layer

\begin{tabular}{ccccccc} 
Layer & Height $(\mathrm{cm})$ & $\theta(\mathrm{mm})$ & Number of cables & Area $\left(\mathrm{cm}^{2}\right)$ & Date (days) \\
\hline 1 & Variable & 12.7 & 10 & 10.14 & 28 \\
\hline
\end{tabular}

ment prestressing. Table 11 presents the coordinates of the four segments of the parable used to draw the curved section of the prestressing tendons. The initial stress value adopted for the prestressing tendons was $147.9 \mathrm{kN} / \mathrm{cm}^{2}$.

Table 12 presents the loading cases used for SLS evaluation. The

Figure 31 - Representation of the parabolic profile along the element (layer 1)

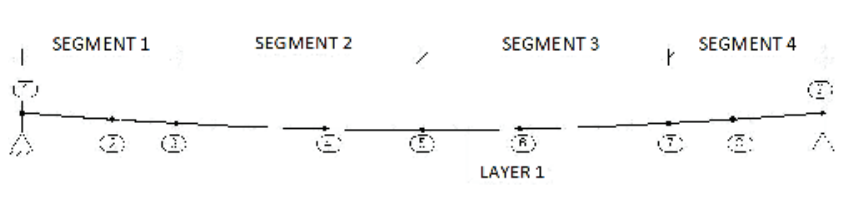

\begin{tabular}{|c|c|c|}
\hline \multicolumn{3}{|c|}{$\begin{array}{c}\text { Table } 11 \text { - Coordinates of the segments } \\
\text { of parabolic profile }\end{array}$} \\
\hline \multicolumn{3}{|c|}{ Coordinates of the segments $1,2,3$ e 4} \\
\hline Position & Section & Height $(\mathrm{cm})$ \\
\hline 1 & 1 & 31 \\
\hline 2 & 10 & 20.8 \\
\hline 3 & $14-15$ & 14.5 \\
\hline 4 & 17 & 6.2 \\
\hline 5 & 18 & 3.4 \\
\hline 6 & 19 & 6.2 \\
\hline 7 & $21-22$ & 14.5 \\
\hline 8 & 26 & 20.8 \\
\hline 9 & 35 & 31 \\
\hline
\end{tabular}

applied loading was calculated and reduced according to the load combination required for service evaluation as determined in each norm. In the SLS-W evaluation, a distributed load of $24 \mathrm{kN} / \mathrm{m}$ (frequent combination) was considered for the Brazilian norm and of 33

\begin{tabular}{|c|c|}
\hline \multicolumn{2}{|c|}{$\begin{array}{l}\text { Figure } 32 \text { - Properties of materials } \\
\text { (Brazilian code specification) }\end{array}$} \\
\hline \multicolumn{2}{|c|}{ 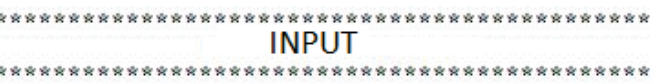 } \\
\hline \multicolumn{2}{|c|}{$* * * \quad$ PROPERTIES OF MATERIALS } \\
\hline & CONCRETE \\
\hline & 1 \\
\hline $\begin{array}{r}\text { Ec: } \\
f c: \\
\mathrm{fcf}: \\
\mathrm{ft}: \\
\mathrm{ec}: \\
\text { ecf } \\
\mathrm{B}: \\
\mathrm{BS}: \\
\text { SPECIFIC WEIGHT } \vdots \\
\text { PERIMETER EXPOSED } \\
\text { DAMP AIR }\end{array}$ & $\begin{array}{r}3541.751000 \\
-4.000000 \\
-.500000 \\
.000100 \\
-.002000 \\
-.010000 \\
1.000000 \\
.400000 \\
.000025 \\
218.000000 \\
80.000000\end{array}$ \\
\hline \multicolumn{2}{|c|}{ PASSIVE REINFORCEMENT } \\
\hline & 1 \\
\hline $\begin{array}{l}\text { E: } \\
\text { ey: } \\
\text { Esh: }\end{array}$ & $\begin{array}{r}21000.000000 \\
.002380 \\
.000000\end{array}$ \\
\hline \multicolumn{2}{|c|}{ ACTIVE REINFORCEMENT } \\
\hline $\begin{aligned} \text { Ep } & = \\
\mathrm{f} 0.01 & = \\
\mathrm{e} 0.01 & = \\
\mathrm{fpu} & = \\
\text { epu } & =\end{aligned}$ & $\begin{array}{r}19500.000000 \\
171.000000 \\
.010000 \\
190.000000 \\
.071000\end{array}$ \\
\hline
\end{tabular}




\section{Table 12 - Load cases for verification of Serviceability Limit State}

\begin{tabular}{|c|c|c|c|}
\hline \multicolumn{4}{|c|}{ Load cases } \\
\hline Cases & Load cases & Initial date (days) & Final date (days) \\
\hline 1 & Weigth T shaped + prestressing & 28 & 28 \\
\hline 2 & Permanent load $\left(g+M_{1 g}+M_{2 g}\right)$ & 28 & 28 \\
\hline 3 & Time effects & 28 & 10,000 \\
\hline 4 & Variable load $\left(q+M_{1 q}+M_{2 q}\right)$ & 10,000 & 10,000 \\
\hline
\end{tabular}

$\mathrm{kN} / \mathrm{m}$ (rare combination) for the French norm. Flexural moments $\mathrm{M}_{1}$ and $\mathrm{M}_{2}$ used to evaluate SLS-W were $\mathrm{M} 1=337 \mathrm{kN} \cdot \mathrm{m}$ and $\mathrm{M} 2=379$ $\mathrm{kN} . \mathrm{m}$ (frequent combination) for the Brazilian norm, and $\mathrm{M} 1=468$ $\mathrm{kN} \cdot \mathrm{m}$ and $\mathrm{M} 2=526 \mathrm{kN} \cdot \mathrm{m}$ (rare combination) for the French norm. The member was analyzed on day 28 , considering prestressing only on the section $\mathrm{T}$, and then adding permanent loading $\left(\mathrm{g}+\mathrm{M}_{1 \mathrm{~g}}\right.$ $+M_{2 g}$ ). Between days 28 and 10,000, the effects of yield, shrinkage, and relaxation on the total sections were calculated. After the analysis of structural behavior relative to time, the last loading portion was added on day 10,000 , corresponding to the reduced variable load $\left(q+M_{1 q}+M_{2 q}\right)$.

After the processing stage, results were analyzed in a post-processing stage. Firstly, input data of the example, such as material properties, are shown in Figure 32. These input data are common to service limit state evaluations performed according to the Brazilian and French norms, and were printed, except for the values of the modulus of elasticity of concrete.

Figure 33 shows a table with the results of the forces correspond- ing to normal stress, shear strength, and flexural moment along the element.

Figure 34 presents normal forces due to prestressing and shear strength along the element. Figure 35 shows the flexural moment relative to loading (frequent combination) and applied prestressing graphs, as well as the total moment graph, representing the sum of the first two graphs. As a parabolic profile was considered for the active reinforcement plotted in the normal force, prestressing moment and total moment graphs, the curve is clearly identified in the prestressing tendons.

Figure 36 presents a table with the cracking width values of all sections, as evaluated according to the Brazilian norm $\left(w_{k}, w_{k 1}\right.$, and $w_{k 2}$ ). Figure 37 shows the strain graph of each passive reinforcement layer and the limit strain recommended by the French norm. Figures 38 and 39 show the cracking tables calculated according to the Brazilian and French norms, respectively. Concrete structural behavior at each horizontal plane of each section of each element is indicated by the values $9,2,1,0,-1$, and -2 , as shown in the figures.

Figure 33 - Cross-section forces (kN, cm) - Brazilian code specification (frequent load combination)

\begin{tabular}{|c|c|c|c|c|c|c|c|c|c|c|c|}
\hline \multirow[b]{2}{*}{ SEC. } & \multirow[b]{2}{*}{ Pos. } & \multicolumn{3}{|c|}{ AXIAL FORCE } & \multicolumn{3}{|c|}{ SHEAR FORCE } & \multicolumn{4}{|c|}{ BENDING MOMENT } \\
\hline & & TOTAL & PRESTRESSING & VARIABLE & TOTAL & PRESTRESSING & VARIABLE & TOTAL & PRES ISO & PRES HIPER & LOAD \\
\hline $\begin{array}{r}1 \\
2 \\
3 \\
4 \\
5 \\
6 \\
7 \\
8 \\
9 \\
10 \\
11 \\
12 \\
13 \\
14 \\
15 \\
16 \\
17 \\
18 \\
19 \\
20 \\
21 \\
22 \\
23 \\
24 \\
25 \\
26 \\
27 \\
28 \\
29 \\
30 \\
31 \\
32 \\
33 \\
34 \\
35\end{array}$ & $\begin{array}{r}.00 \\
8.49 \\
26.56 \\
50.00 \\
73.44 \\
91.51 \\
100.00 \\
100.00 \\
112.73 \\
139.84 \\
175.00 \\
210.16 \\
237.27 \\
250.00 \\
250.00 \\
317.23 \\
460.34 \\
646.00 \\
831.66 \\
974.77 \\
1042.00 \\
1042.00 \\
1054.73 \\
1081.84 \\
1117.00 \\
1152.16 \\
1179.27 \\
1192.00 \\
1192.00 \\
1200.49 \\
1218.56 \\
1242.00 \\
1265.44 \\
1283.51 \\
1292.00\end{array}$ & $\begin{array}{l}-1260.59 \\
-1260.70 \\
-1260.93 \\
-1261.22 \\
-1261.49 \\
-1261.70 \\
-1261.79 \\
-1261.79 \\
-1261.93 \\
-1262.21 \\
-1262.56 \\
-1262.88 \\
-1263.11 \\
-1263.22 \\
-1263.08 \\
-1263.58 \\
-1264.37 \\
-1264.81 \\
-1264.37 \\
-1263.58 \\
-1263.08 \\
-1263.22 \\
-1263.11 \\
-1262.88 \\
-1262.56 \\
-1262.21 \\
-1261.93 \\
-1261.79 \\
-1261.79 \\
-1261.70 \\
-1261.49 \\
-1261.22 \\
-1260.93 \\
-1260.70 \\
-1260.59\end{array}$ & $\begin{array}{l}-1260.59 \\
-1260.70 \\
-1260.93 \\
-1261.22 \\
-1261.49 \\
-1261.70 \\
-1261.79 \\
-1261.79 \\
-1261.93 \\
-1262.21 \\
-1262.56 \\
-1262.88 \\
-1263.11 \\
-1263.22 \\
-1263.08 \\
-1263.58 \\
-1264.37 \\
-1264.81 \\
-1264.37 \\
-1263.58 \\
-1263.08 \\
-1263.22 \\
-1263.11 \\
-1262.88 \\
-1262.56 \\
-1262.21 \\
-1261.93 \\
-1261.79 \\
-1261.79 \\
-1261.70 \\
-1261.49 \\
-1261.22 \\
-1260.93 \\
-1260.70 \\
-1260.59\end{array}$ & $\begin{array}{l}.00 \\
.00 \\
.00 \\
.00 \\
.00 \\
.00 \\
.00 \\
.00 \\
.00 \\
.00 \\
.00 \\
.00 \\
.00 \\
.00 \\
.00 \\
.00 \\
.00 \\
.00 \\
.00 \\
.00 \\
.00 \\
.00 \\
.00 \\
.00 \\
.00 \\
.00 \\
.00 \\
.00 \\
.00 \\
.00 \\
.00 \\
.00 \\
.00 \\
.00\end{array}$ & $\begin{array}{r}-158.68 \\
-156.54 \\
-152.00 \\
-146.10 \\
-140.20 \\
-135.66 \\
-133.52 \\
-133.52 \\
-130.32 \\
-123.51 \\
-114.67 \\
-105.83 \\
-99.02 \\
-95.82 \\
-93.08 \\
-75.94 \\
-39.46 \\
3.23 \\
45.92 \\
82.39 \\
99.53 \\
102.27 \\
105.47 \\
112.28 \\
121.12 \\
129.96 \\
136.77 \\
139.98 \\
139.98 \\
142.11 \\
146.66 \\
152.55 \\
158.45 \\
163.00 \\
165.13\end{array}$ & $\begin{array}{r}103.29 \\
101.94 \\
99.07 \\
95.34 \\
91.62 \\
88.74 \\
87.39 \\
87.39 \\
85.37 \\
81.06 \\
75.46 \\
69.87 \\
65.55 \\
63.52 \\
66.26 \\
55.80 \\
33.53 \\
.00 \\
-33.53 \\
-55.80 \\
-66.26 \\
-63.52 \\
-65.55 \\
-69.87 \\
-75.46 \\
-81.06 \\
-85.37 \\
-87.39 \\
-87.39 \\
-88.74 \\
-91.62 \\
-95.34 \\
-99.07 \\
-101.94 \\
-103.29\end{array}$ & $\begin{array}{r}-261.97 \\
-258.48 \\
-251.07 \\
-241.44 \\
-231.82 \\
-224.40 \\
-220.92 \\
-220.92 \\
-215.69 \\
-204.56 \\
-190.13 \\
-175.69 \\
-164.57 \\
-159.34 \\
-159.34 \\
-131.74 \\
-72.99 \\
3.23 \\
79.45 \\
138.19 \\
165.79 \\
165.79 \\
171.02 \\
182.15 \\
196.58 \\
211.02 \\
222.14 \\
227.37 \\
227.37 \\
230.86 \\
238.27 \\
247.90 \\
257.52 \\
264.94 \\
268.42\end{array}$ & $\begin{array}{r}-36029.05 \\
-34689.43 \\
-31898.86 \\
-28401.70 \\
-25043.70 \\
-22550.37 \\
-21407.49 \\
-21407.49 \\
-19727.34 \\
-16287.47 \\
-12100.99 \\
-8226.41 \\
-5452.64 \\
-4213.38 \\
-4210.81 \\
1464.01 \\
9705.06 \\
12628.23 \\
8506.92 \\
-657.62 \\
-6766.30 \\
-6768.87 \\
-8090.30 \\
-11038.97 \\
-15140.48 \\
-19553.88 \\
-23168.64 \\
-24930.97 \\
-24930.97 \\
-26128.62 \\
-28738.56 \\
-32247.83 \\
-35896.28 \\
-38803.45 \\
-40197.85\end{array}$ & $\begin{array}{r}-2303.53 \\
-3172.93 \\
-4985.84 \\
-7261.49 \\
-9450.72 \\
-11079.06 \\
-11826.30 \\
-11826.30 \\
-12925.86 \\
-15181.09 \\
-17934.01 \\
-20491.23 \\
-22328.51 \\
-23151.44 \\
-23148.86 \\
-27258.85 \\
-33666.82 \\
-37220.13 \\
-33666.82 \\
-27258.85 \\
-23148.86 \\
-23151.44 \\
-22328.51 \\
-20491.23 \\
-17934.01 \\
-15181.09 \\
-12925.86 \\
-11826.30 \\
-11826.30 \\
-11079.06 \\
-9450.72 \\
-7261.49 \\
-4985.84 \\
-3172.93 \\
-2303.53\end{array}$ & $\begin{array}{l}.00 \\
.00 \\
.00 \\
.00 \\
.00 \\
.00 \\
.00 \\
.00 \\
.00 \\
.00 \\
.00 \\
.00 \\
.00 \\
.00 \\
.00 \\
.00 \\
.00 \\
.00 \\
.00 \\
.00 \\
.00 \\
.00 \\
.00 \\
.00 \\
.00 \\
.00 \\
.00- \\
.00 \\
.00 \\
.00 \\
.00 \\
.00 \\
.00 \\
.00 \\
.00\end{array}$ & $\begin{array}{r}-33725.52 \\
-31516.50 \\
-26913.03 \\
-21140.21 \\
-15592.99 \\
-11471.31 \\
-9581.19 \\
-9581.19 \\
-6801.48 \\
-1106.39 \\
5833.02 \\
12264.83 \\
16875.87 \\
18938.05 \\
18938.05 \\
28722.86 \\
43371.88 \\
49848.36 \\
42173.74 \\
26601.23 \\
16382.57 \\
16382.57 \\
14238.22 \\
9452.26 \\
2793.54 \\
-4372.79 \\
-10242.79 \\
-13104.67 \\
-13104.67 \\
-15049.56 \\
-19287.84 \\
-24986.34 \\
-30910.44 \\
-35630.52 \\
-37894.32\end{array}$ \\
\hline
\end{tabular}


Figure 34 - Axial and Shear forces - Brazilian code specification (frequent load combination)

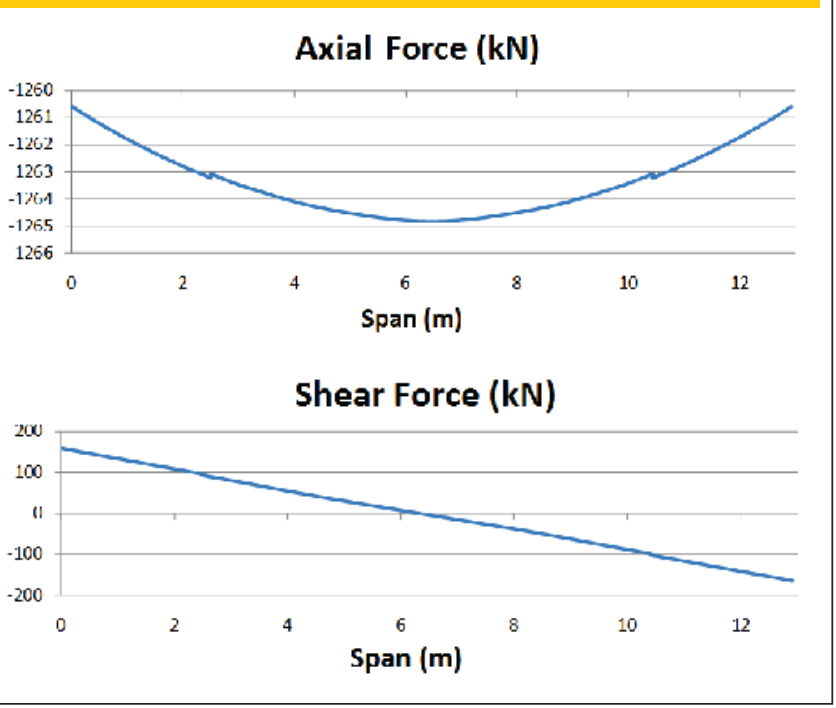

Based on the cracking tables of this second example, most sections were still completely compressed at the end of SLS evaluation. It was observed that, according to both Brazilian and French norms, most lower and central fibers were still compressed (-1), differently from the upper fibers, close to the supports, which already showed some cracking (2). In the central section, between horizontal planes 1 and 5 (French norm), there was another cracked concrete zone (2), and the passive reinforcement layers were still not tensioned. Therefore, crack width was determined only for the upper edge of the regions close to the beam ends, where passive reinforcements of layers 4 and 6 were already tensioned.

In the SLS-W analysis according to the Brazilian norm, out of the 35 sections along the element, crack width values were calculated only for the six sections located at the beam ends (sections 1, 2 and 32 to 35 ). The maximal crack width value found in the analysis $\left(w_{k}=0.01016 \mathrm{~mm}\right)$ was lower than that established by the Brazilian norm $\left(w_{k, l i m}=0.2 \mathrm{~mm}\right)$, thereby ensuring the member safety regarding SLS-W.

A similar situation was observed in the evaluation of excessive strain service limit state (SLS-DEF), with a probable sagging value equal to 0.004 , which is lower than the allowed sagging (span/250) value of $5.17 \mathrm{~cm}$. According to the designer, this beam presented virtually null sagging after total loading was applied, thereby validating the

Figure 35 - Bending Moment - Brazilian code specification (frequent load combination)

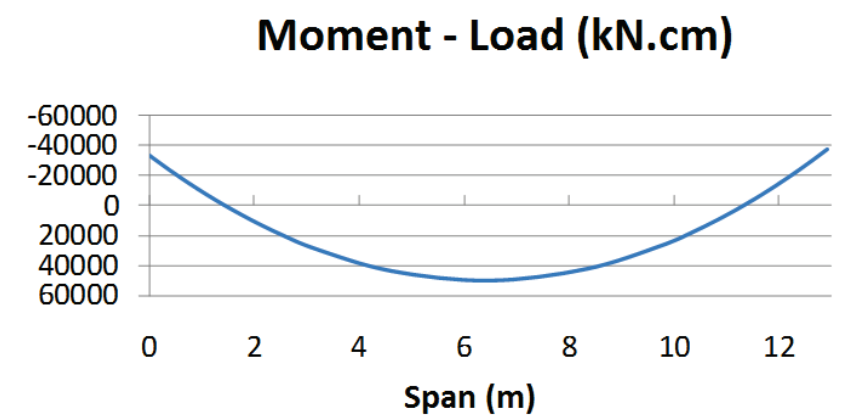

Moment - Prestressing (kN.cm)

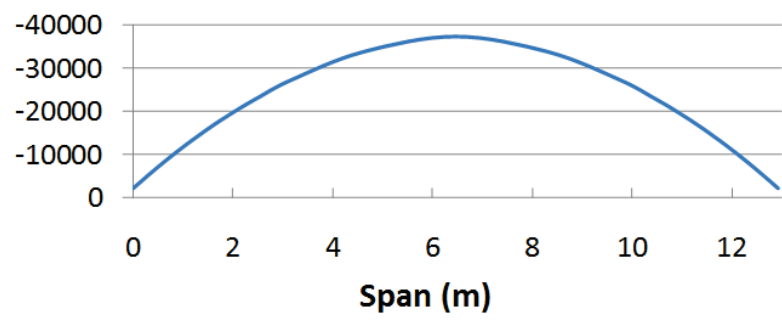

\section{Moment - Total (kN.cm)}

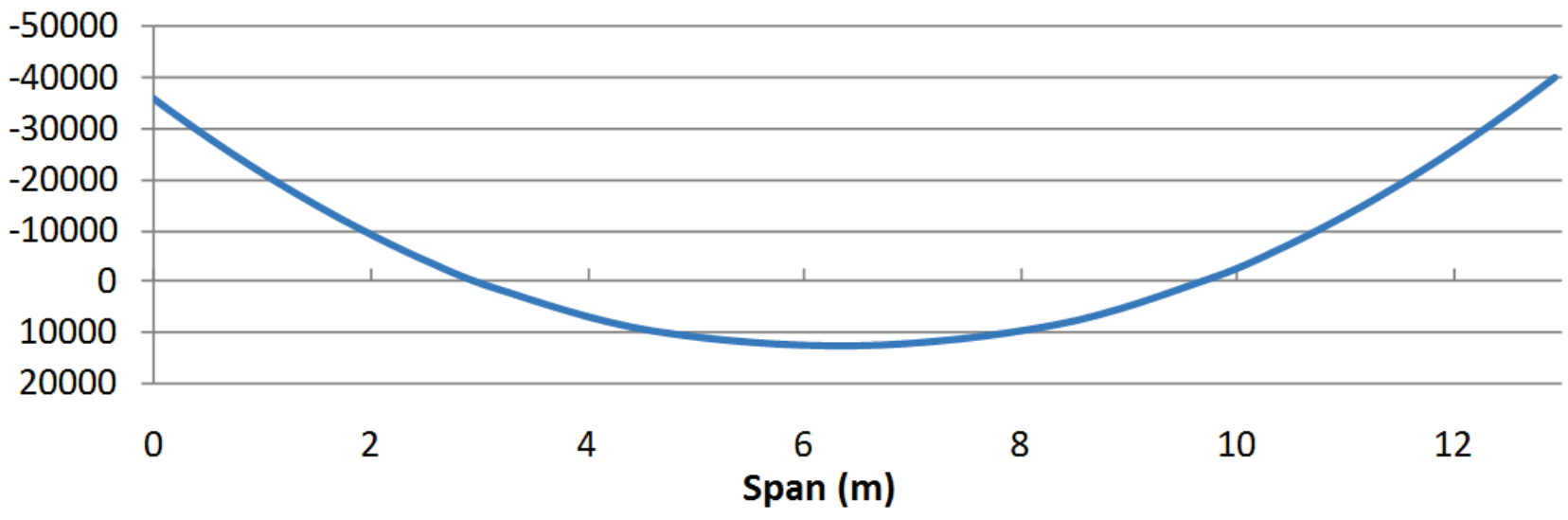




\begin{tabular}{|c|c|c|c|}
\hline \multicolumn{4}{|c|}{$\begin{array}{l}\text { Figure } 36 \text { - Crack width along the } \\
\text { sections }(\mathrm{mm}) \text { - Brazilian code } \\
\text { specification (frequent load combination) }\end{array}$} \\
\hline \multicolumn{4}{|c|}{ ** CRACK WIDTH - WK (mm) } \\
\hline \multicolumn{2}{|c|}{ ** LIMIT CRACK WIDTH = } & \multirow[b]{2}{*}{ WK2 } & \multirow[b]{2}{*}{ WK } \\
\hline SECTION & WK1 & & \\
\hline $\begin{array}{r}1 \\
1 \\
3 \\
3 \\
4 \\
5 \\
6 \\
7 \\
8 \\
9 \\
10 \\
11 \\
12 \\
13 \\
14 \\
15 \\
16 \\
17 \\
18 \\
19 \\
20 \\
21 \\
22 \\
23 \\
24 \\
25 \\
26 \\
27 \\
28 \\
29 \\
30 \\
31 \\
32 \\
33 \\
34 \\
35\end{array}$ & $\begin{array}{l}.0037512937 \\
.0024496383 \\
.000000000 \\
.00000000000 \\
.0000000000 \\
.00000000000 \\
.0000000000 \\
.0000000000 \\
.00000000000 \\
.00000000000 \\
.00000000000 \\
.00000000000 \\
.0000000000 \\
.00000000000 \\
.0000000000 \\
.00000000000 \\
.0000000000 \\
.000000000000 \\
.00000000000 \\
.00000000000 \\
.00000000000 \\
.00000000000 \\
.0000000000 \\
.00000000000 \\
.0000000000 \\
.00000000000 \\
.0000000000 \\
.0000000000 \\
.00000000000 \\
.0000000000 \\
.0038629265 \\
.0087111444 \\
.0101605859\end{array}$ & $\begin{array}{l}.0687873156 \\
.0555864331 \\
.000000000 \\
.0000000000 \\
.0000000000 \\
.0000000000 \\
.0000000000 \\
.00000000000 \\
.00000000000 \\
.00000000000 \\
.00000000000 \\
.00000000000 \\
.0000000000 \\
.0000000000 \\
.0000000000 \\
.00000000000 \\
.0000000000 \\
.00000000000 \\
.0000000000 \\
.0000000000 \\
.00000000000 \\
.00000000000 \\
.00000000000 \\
.0000000000 \\
.0000000000 \\
.0000000000 \\
.0000000000 \\
.0000000000 \\
.0000000000 \\
.0000000000 \\
.0000000000 \\
.0143355285 \\
.0698629923 \\
.1048227032 \\
.1132080227\end{array}$ & $\begin{array}{l}.0037512937 \\
.0024496383 \\
.000000000 \\
.0000000000 \\
.0000000000 \\
.0000000000 \\
.0000000000 \\
.0000000000 \\
.00000000000 \\
.00000000000 \\
.00000000000 \\
.00000000000 \\
.0000000000 \\
.0000000000 \\
.0000000000 \\
.0000000000 \\
.0000000000 \\
.0000000000 \\
.0000000000 \\
.0000000000 \\
.0000000000 \\
.00000000000 \\
.00000000000 \\
.0000000000 \\
.00000000000 \\
.0000000000 \\
.00000000000 \\
.0000000000 \\
.0000000000 \\
.0000000000 \\
.0000000000 \\
.0001629265 \\
.0038695344 \\
.0087111412 \\
.0101605859\end{array}$ \\
\hline
\end{tabular}

Figure 37 - Deformation of passive reinforcement layers - French code specification (rare load combination)

\section{Deformation of passive reinforcement layers}

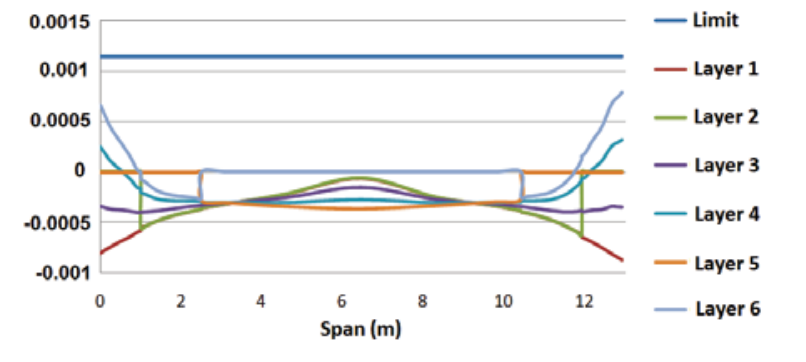

result obtained with the numerical model. Figure 40 shows the graph relative to transversal displacement along the beam span.

Analyzing the strain graphs of each passive reinforcement layer according to the French norm, it is observed that layers 4 and 6 present tensile stresses in the 15 sections located at the beam ends. In these sections, reinforcement layer tensile stress was compared with limit stress. As the corresponding limit strain is equal to $1.143 \%$, that is, approximately 1.45 times higher than the obtained maximal strain $(0.7866 \%)$, beam safety is ensured relative to SLS-W.

After ULS evaluation, ultimate moment values resulting from ultimate loading were compared with resistant moment values.

\section{Figure 38 - Cracking table - Brazilian code specification (frequent load combination)}

VERIFICATION - BRAZILIAN CODE SPECIFICATION - NBR6118

PRESTRESSED CONCRETE

PARTIAL PRESTRESSING - NIVEL 1

FREQUENT COMBINATION LOAD

NONLINEAR BEHAVIOR OF CONCRETE

VERIFICATION OF ELS-W - PASSIVE REINFORCEMENT

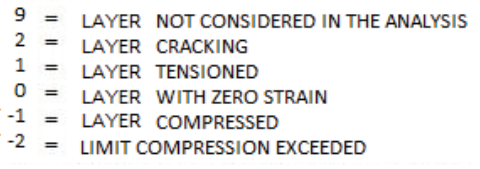

LAYER SECTIONS

ELEMENT 1

$\begin{array}{lllllllllllllllllllllllllllllllllllllll}1 & 2 & 3 & 4 & 5 & 6 & 7 & 8 & 9 & 10 & 11 & 12 & 13 & 14 & 15 & 16 & 17 & 18 & 19 & 20 & 21 & 22 & 23 & 24 & 25 & 26 & 27 & 28 & 29 & 30 & 31 & 32 & 33 & 34 & 35\end{array}$

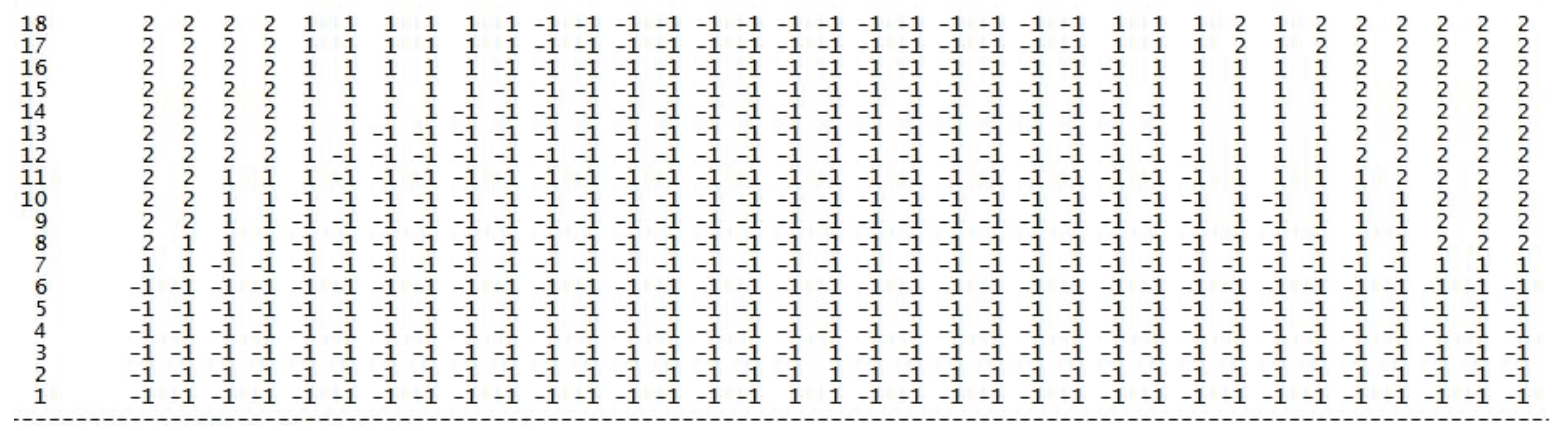

RESULTS: THE ELS-W NOT EXCEEDED 
Figure 39 - Tab Cracking table - French code specification (rare load combination)

VERIFICATION - FRENCH CODE SPECIFICATION - BPEL91

PRESTRESSED CONCRETE

PARTIAL PRESTRESSING - CLASSE III

RARE COMBINATION LOAD

NONLINEAR BEHAVIOR OF CONCRETE

VERIFICATION OF ELS-W - PASSIVE REINFORCEMENT

$9=$ LAYER NOT CONSIDERED IN THE ANALYSIS

$2=$ LAYER CRACKING

1 = LAYER TENSIONED

= LAYER WITH ZERO STRAIN

= LAYER COMPRESSED

$=$ LIMIT COMPRESSION EXCEEDED

ELEMENT 1

LAYER SECTIONS

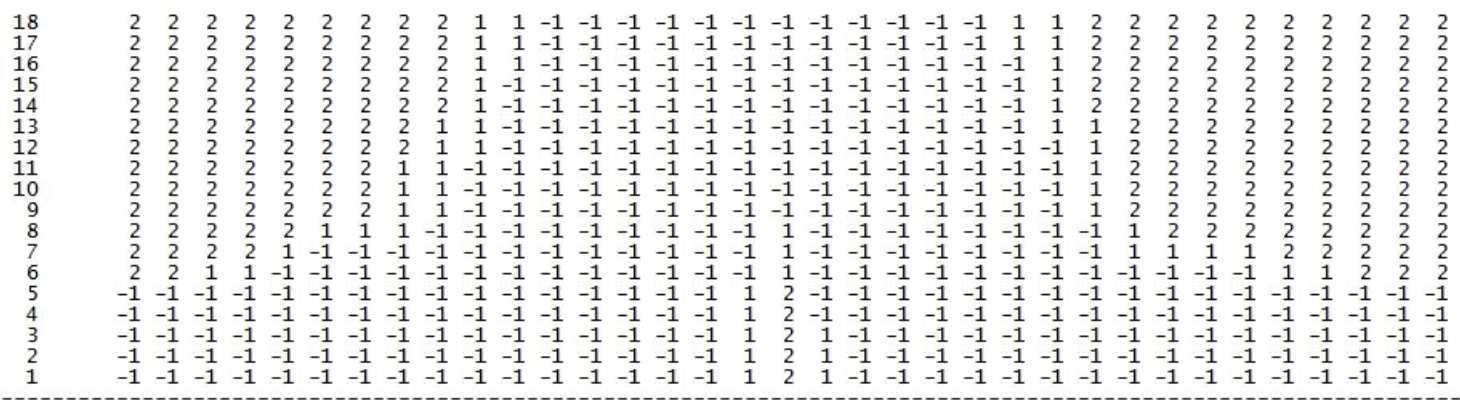

RESULTS: THE ELS-W NOT EXCEEDED

According to the criteria of the Brazilian norm, resistant moment was $829.2 \mathrm{kN} . \mathrm{m}$ and ultimate moment was $771.9 \mathrm{kN} . \mathrm{m}$. The comparison of these values shows that the member has an additional safety factor equal to 1.07 relative to breaking. When using the French norm, the resistant moment value $(807$ $\mathrm{kN} . \mathrm{m})$ was 1.06 times higher than the ultimate moment (764.2 $\mathrm{kN} . \mathrm{m}$ ), which is lower than that obtained with the Brazilian norm due to different load increment coefficients. As in the previous example, in both cases ultimate moment was lower than the resistant moment, and therefore, element safety relative to rupture is ensured.

\section{Final considerations}

The increasing use of prestressing in Brazil and around the world

Figure 40 - Transversal displacement

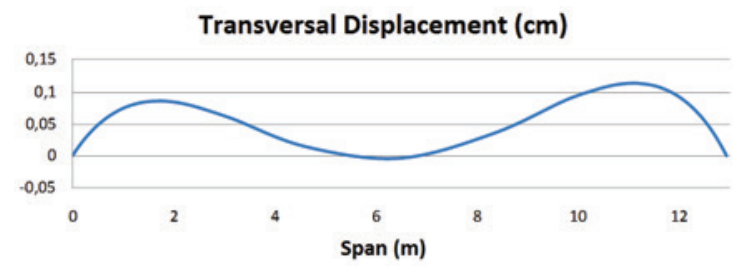

justifies the automation of design procedures of bonded and unbonded prestressed concrete elements mainly due to its building advantages, as well as allowing reducing crack incidence and element dimensions by the use of more resistant materials. Based on the implementation of evaluation subroutines in the software program according the recommendations of the Brazilian and French norms, it is possible to directly apply the finite element numerical model in the design of prestressed concrete elements.

As expected, service limit state evaluations relative to cracking of the studied bonded and unbonded prestressing beams performed according to the Brazilian and French norms yielded very similar results, despite using different approaches. However, the French norm approached proved to be simpler and faster, demanding much less computational efforts.

Relative to ultimate limit state, it was observed that the safety margin obtained using the procedures of both norms were very similar.

\section{Acknowledgements}

The authors express their gratitude to CAPES (Coordenação de Aperfeiçoamento de Pessoal de Nível Superior), CNPq (Conselho Nacional de Desenvolvimento Científico e Tecnológico) and RS Engenharia for their support.

\section{References}

[01] RUDLOFF. Technical catalog. 2006. Available: < http://www.rudloff.com.br/>. Accessed on April 12, 2010.

[02] BARBIERI, R. A. Modelo Numérico para Análise à 
Flexão de Elementos Estruturais com Protensão Aderente e Não Aderente. 2003. 330 p. Tese (Doutorado em Engenharia Civil) - Universidade Federal do Rio Grande do Sul, Porto Alegre.

[03] LAZZARI, P. M. Implementação de Rotinas Computacionais para o Projeto Automático de Peças em Concreto com Protensão Aderente e Não Aderente. 2011. 173 p. Dissertação (Mestrado em Engenharia Civil) - Programa de Pós-Graduação em Engenharia Civil, UFRGS, Porto Alegre.

[04] BARBIERI, R. A.; GASTAL, F.P.S.L.; CAMPOS FILHO, A. Numerical Model for the Analysis of Unbonded Prestressed Members. Journal of Structural Engineering (ASCE), New York, v. 132, p. 34-42, 2006.

[05] VOELCKER, M. Análise dos Fatores Influentes na Tensão Última de Protensão em Cabos Não Aderentes. 2004. 159 p. Dissertação (Mestrado em Engenharia Civil) - Programa de Pós-Graduação em Engenharia Civil, UFRGS, Porto Alegre.

[06] KABAILA, A.; SAENZ, L. P.; TULIN, L. G.; GERSTLE, K. H. Equation for the Stress-Strain Curve of Concrete. $\mathrm{ACl}$ Journal, Farmington Hills, $\mathrm{ACl}$, v.61, n. 3, p.1227-1239, Mar. 1964.

[07] GHALI, A.; FAVRE. Concrete Structures: Stresses and Deformations. London: Chapman and Hall, 1986.

[08] OWEN, D. R. J.; FIGUEIRAS, J. Ultimate Load Analysis of Reinforced Concrete Plates Including Geometric Nonlinear Effects. In: Finite Elements Software for Plates and Shells. 1984. Hinton, E.; Owen, D. R. J., Pineridge press, Swansea, 1984.

[09] DEVALAPURA, R. K.; TRADOS, M. K. Stress-Strain Modelling of 270 ksi Low-Relaxation Prestressing Strands. PCI Journal, Chicago, PCl, v.37, n.2, p.100-106, Mar-Apr. 1992.

[10] ASSOCIAÇÃO BRASILEIRA DE NORMAS TÉCNICAS. Projeto de estruturas de concreto - Procedimento NBR 6118, Rio de Janeiro, 2007.

[11] BPEL 91. Règles techniques de conception et de calcul des ouvrages et reconstructions en béton précontraint suivant la méthode des états limites. Paris, 1992.

[12] THONIER, H. Le Béton Précontraint aux Etats-limites. 2. ed. Paris: Presses de l'Ecole Nationale des Ponts et Chaussées, 1992.

[13] SCHWINGEL, R. C. Projetos do Escritório de Cálculo Estrutural RS Engenharia Ltda., 2011. 